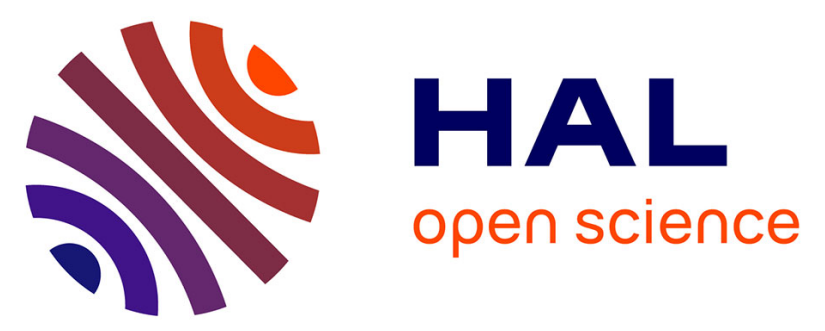

\title{
A trait-based analysis to assess the ability of cover crops to control weeds in a tropical island
}

\author{
Mathias Christina, Adrien Négrier, Pascal Marnotte, Pauline Viaud, Alizé \\ Mansuy, Sandrine Auzoux, Patrick Techer, Emmanuel Hoarau, André \\ Chabanne
}

\section{To cite this version:}

Mathias Christina, Adrien Négrier, Pascal Marnotte, Pauline Viaud, Alizé Mansuy, et al.. A traitbased analysis to assess the ability of cover crops to control weeds in a tropical island. European Journal of Agronomy, 2021, 128, 10.1016/j.eja.2021.126316 . hal-02612563v4

\section{HAL Id: hal-02612563 \\ https://hal.science/hal-02612563v4}

Submitted on 27 May 2021

HAL is a multi-disciplinary open access archive for the deposit and dissemination of scientific research documents, whether they are published or not. The documents may come from teaching and research institutions in France or abroad, or from public or private research centers.
L'archive ouverte pluridisciplinaire $\mathbf{H A L}$, est destinée au dépôt et à la diffusion de documents scientifiques de niveau recherche, publiés ou non, émanant des établissements d'enseignement et de recherche français ou étrangers, des laboratoires publics ou privés.

\section{다(1)(2)}

Distributed under a Creative Commons Attribution - ShareAlikel 4.0 International 


\title{
A trait-based analysis to assess the ability of cover crops to control weeds in a tropical island
}

Christina $\mathrm{M}^{1,2^{*}}$, Negrier $\mathrm{A}^{3,4}$, Marnotte $\mathrm{P}^{1,2}$, Viaud $\mathrm{P}^{1,2}$, Mansuy $\mathrm{A}^{5}$, Auzoux $\mathrm{S}^{1,2}$, Techer $\mathrm{P}^{2,6}$, Hoarau $E^{1,2}$, Chabanne $A^{2,7}$

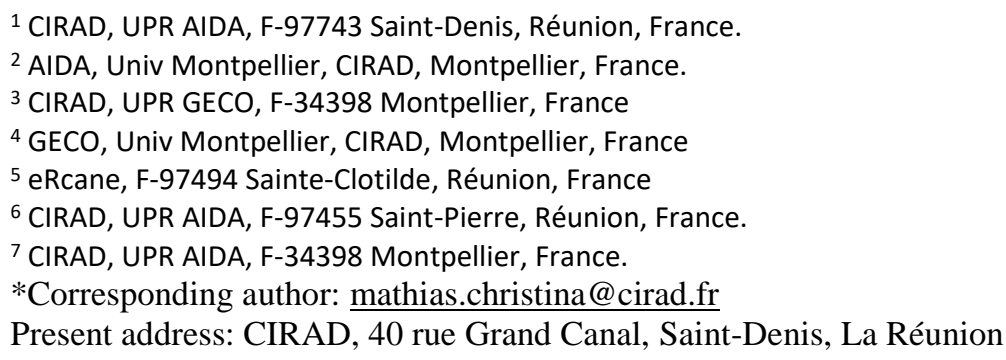

\section{Highlights}

- Performances of 46 cover crop species assessed in Reunion Island over three years.

- Plant height and leaf appearance rate were traits maximizing ground cover.

- Weed control provided by pure and mixed cover crops was similar.

- Weed control was more efficient with species with high biomass and height.

\begin{abstract}
Cover crops have a high potential to manage weeds through competition for shared resources in tropical agrosystems. Assessing the abilities of a large number of different plant species to compete with weeds requires experiments in different pedo-climatic environments. Our study was based on a set of 10 trials including 46 species of cover crops performed from 2016 to 2018 in three sites in Reunion Island. Our aim was to identify and measure plant traits of cover crops that maximize ground cover and weed control under a tropical climate. We characterized two traits of interest (mean ground cover and rate of increase in ground cover) and compared the family, area of origin and life cycle of the cover crops. The ability of cover crops to cover the soil increased with rate of increase in height and leaf appearance rate and tended to decrease with thermal time for emergence. Accordingly, weed control efficiency (low weed cover and dry mass) was positively correlated with ground cover, height and biomass. Using functional traits to characterize plant species enabled us to identify cover crops that could be used in tropical agrosystems as an alternative to herbicides, for instance, on sugarcane in Reunion Island.
\end{abstract}

Keywords: functional traits; cover plants; companion plants; weeds; Reunion Island; sugarcane 


\section{Introduction}

Weeds are a major biotic constraint to tropical agriculture (FAO, 2017) as they can reduce both the quality and quantity of the crop yield, as well as increase the crop production costs (Oerke, 2006; FAO, 2017). Weeds not only compete with the main crop for light, water and nutrient ressources (Cordeau and Moreau, 2017), but are alternative hosts for crop pests and pathogens (FAO, 2017). Weeds grow fast all year round thanks to the favorable climate in most tropical areas. As a result, large quantities of chemical inputs are used with herbicides representing a large proportion of the active ingredients (Oerke and Dehne, 2004).

Use of cover crops to control weeds before planting (Lu et al., 2000) or as a companion crop during crop growth (Vandermeer, 1992) are ways to reduce herbicide inputs in tropical agrosystems (e.g. Bhaskar et al., 2018; Mennan et al., 2000; Ranaivoson et al., 2018). Cover crops are thus increasingly used in innovative cropping systems to favor biological regulation and to deliver agro-ecosystem services such as improving soil fertility and controlling pests, weeds and erosion (Altieri et al., 2011; Kocira et al., 2020; Koohafkan et al., 2012; Snapp et al., 2005). A wide range of cover crops are available, so the choice of species to deliver these services is crucial because the spatial and temporal combinations with the main crop will determine the performances of the system (Malezieux et al., 2009).

The mechanisms underlying biological weed control using cover crops are complex. They can be direct through competition for resources, allelopathy or by providing a physical barrier to germination and emergence (Médiène et al., 2011; Teasdale et al., 2007), or indirect by enhancing seed predators or fungi that cause damping off (Cordeau and Moreau, 2017). In intensive tropical agrosystems, the process of competition especially for light is mainly put forward to explain weed control by cover crops. The other resources (high fertilization rates, high rainfall or irrigation) are seldom limiting for plant growth. The ability of a plant species to compete for light may result from its ability to access light for its own use (e.g. overgrowth ability) or to reduce access to light by its neighbors (e.g. shading). Assessing the efficiency of the processes of light interception, light conversion, and carbon allocation can be challenging when studying a wide range of cover crops.

One way of choosing and comparing possible cover crops is identifying morpho-physiophenological features, recently referred to as plant functional traits (Garnier and Navas 2012, Violle 2007), that maximize weed control. A large literature has highlighted how plant traits such as cover crop biomass (Mennan et al., 2020, Teasdale et al., 2007), height (Korres and Froud-Williams, 2002), rapid germination (Pester et al., 1999), large leaf area development (Seavers and Wright, 1999) or early light interception (Kruidhof et al., 2008) affect the interactions between the main crop and the weeds. However, the effectiveness of cover crops in weed control often depends on the composition of weed population as well as management practices (Osipitan et al., 2019).

In Reunion Island, weed pressure is a major constraint for agriculture. The aim of the 2008 Ecophyto I and 2018 Ecophyto II program is to reduce the use of herbicides in the French agricultural sector by $50 \%$ by 2025 . In Reunion Island, sugarcane, the main agro-industrial 
sector, plays an important economic, societal, and environmental role as it uses more than 50\% of agricultural land (Agreste, 2016). The largest amount of herbicides on Reunion Island are used for sugarcane production (Antoir et al., 2016). Consequently, cover crops have a strong potential in the sugarcane sector (Mansuy et al., 2019).

The aim of this study was to perform trait-based characterization of a wide range of cover crops to assess their ability to control weeds in tropical agrosystems, using Reunion Island as a case study. Specifically, our three objectives were to use the range of cover crop species i) to identify the species with the highest ground cover in tropical climatic conditions, ii) to identify the crop traits that maximize ground cover, and iii) to assess the ability of cover crops to control weed growth.

To achieve these objectives, we conducted a set of 10 field experiments in Reunion Island from 2016 to 2018. Six were designed to assess the performance of the cover crops in response to local climate (i.e. weeds were controlled manually). The other four experiments were designed to assess the ability of cover crops to control weeds.

\section{Materials and methods}

\subsection{Description of the trials}

The trials were conducted in three experimental stations in Reunion Island between February and June (warm season and beginning of the cool season) from 2016 to 2018. Table 1 lists the locations and give the details on each trial. Soil characteristics at the three sites are listed in Supplementary Information A Table A1. Two main types of trials were performed: trials to choose the cover crop that grows best in the local climate (hereafter 'cover crop trial'), and trials to test which cover crop is best at weed control (hereafter 'weed control trial'). In the cover crop trials, weeds were removed manually after sowing and throughout the trial. Four cover crop trials were performed in La Mare (50 m asl, 2016 to 2018), one in Bassin Plat (160 m asl, 2016) and one in Colimaçons (800 m asl, 2016). Each trial comprised $12 \mathrm{~m}^{2}$ or $16 \mathrm{~m}^{2}$ plots containing pure cover crops. The growth period of the cover crops ranged from 2.5 to 4 months depending on the trial due to logistic reasons. In the weed control trials, weeds were not removed after sowing to assess competition between the cover crops and the weeds. Three weed control trials were performed in La Mare (2016, 2017) and one in Bassin Plat (2017) in plots ranging from 20 to $100 \mathrm{~m}^{2}$. The growth period of the cover crops was two months. In all weed control trials, the plots containing the cover crops were located next to control plots containing natural weed flora. The dominant weed flora present in La Mare and Bassin Plat are listed in Supplementary Information Table A2. In all sites, the daily average temperature (TMEAN) was measured. Five of the trials were fertilized at sowing while the other five were not fertilized. Fertilizer applications are described in Table 1. All the trials were irrigated except at Colimaçons, where precipitation was $>120 \mathrm{~mm} \mathrm{month}^{-1}$ during the growth period. Prior to sowing, the plots were tilled down to $15 \mathrm{~cm}$ using tines and herbicide was applied. Seeds were sown manually in lines with $40 \mathrm{~cm}$ interrow spacing at a depth of $2-5 \mathrm{~cm}$. The sowing density for each species is listed 
in Supplementary Information Table A3 and was determined from the literature, advice from suppliers and in-house expertise. The experimental design of each trial is given in Figs. A1 to A10.

\subsection{Cover crop species}

A total of 46 cover crop species were tested in the different trials. Details on the cover crop species used in each experiment are listed in Tables A3, A4 and A5. The species included Asteraceae $(n=2)$, Brassicaceae $(n=3)$, Fabaceae $(n=32)$, Poaceae $(n=8)$ and Polygonaceae $(\mathrm{n}=1)$ plants. Among them, 21 are temperate and 25 are tropical species. Species were annual $(n=36)$ or perennial $(n=10)$. Their growth habit (creeping, erect or vines) is detailed in Table A4. In some cover crop trials (see the experimental design in Supplementary Information Figs A1 to A10), several cultivars were used in the same trial but in the analyses, they were considered as the same species. In the weed control trials, 18 cover crop mixtures were also tested (Table 1), the mixtures are detailed in Table A5, each mix included two species.

\subsection{Measurements}

Cover crop traits and phenology were measured in the different trials (Table 2). Ground cover by crops $(\mathrm{COV}, \%)$ was measured in each plot weekly using a visual notation method described in Supplementary Information Table A6 and already used in previous studies (Mansuy et al., 2019; Mathieu \& Marnotte, 2000; Marnotte et al., 1984). This method makes it possible to assess the soil cover of individual species in multi-species crops (e.g. cover crops and weeds). Between two measurement dates, ground cover was linearly extrapolated each day. Then, we calculated a mean ground cover $\left(\mathrm{COV}_{\mathrm{MEAN}}, \%\right)$ as the average interpolated COV from sowing to the end of the trial. This mean cover was used to estimate the capacity of species to cover the soil durably. The maximum cover ( $\left.\mathrm{COV}_{\mathrm{MAX}}, \%\right)$ was defined as the maximum value of cover reached by the species concerned. A rate of increase in ground cover per day (COV RATE, \% d $\mathrm{d}^{-}$ ${ }^{1}$ ) was calculated as the $\mathrm{COV}_{\mathrm{MAX}}$ divided by the number of days needed to reach it after sowing. Additionally, for each species, the height and number of leaves of five individuals per plot were measured weekly and averaged per date. From these measurements, a rate of increase in height $\left(\mathrm{H}_{\mathrm{RATE}}, \mathrm{cm} \mathrm{d}^{-1}\right)$ and a leaf appearance rate (Leaf $\mathrm{RATE}, \mathrm{n} \mathrm{d}^{-1}$ ) were calculated from emergence to flowering as the ratio between plant height or leaf number and the number of days since sowing. Regarding phenology measurements, the thermal times for emergence (Emerg ${ }_{S D D},{ }^{\circ} \mathrm{d}$ ) and flowering (FlosDD, ${ }^{\circ} \mathrm{d}$ ) were calculated as the sum of daily $\mathrm{T}_{\text {MEAN }}$ from sowing to the point at which $50 \%$ of plants had emerged or flowered. Finally, to measure aboveground dry mass $\left(A B V_{D M}\right)$ in weed control trials, all weeds and cover crops in three $50 x 50 \mathrm{~cm}$ squares inside each plot were cut at ground level after two months of growth, i.e., at the end of the weed control experiment, separated before weighing and dried at $60^{\circ} \mathrm{C}$ for 2 days. 
Table 1. Cover crop and weed control trials. The cover crop species used in the different trials are listed in Table A3. For each trial, the site, latitude, longitude, altitude, soil type (WRB classification), year, average temperature ( $\left.T_{M E A N}\right)$, number of species, plot area, sowing date, trial duration, fertilization regime are given.

\begin{tabular}{|c|c|c|c|c|c|c|c|c|c|c|c|c|c|c|}
\hline $\begin{array}{l}\text { Trial } \\
\text { type }\end{array}$ & Site & Latitude & Longitude & Altitude & Soil type & Year & $\mathbf{T}_{\text {MEAN }}$ & $\begin{array}{c}\text { Number of } \\
\text { species } \\
\text { (+ mixture) }\end{array}$ & $\begin{array}{c}\text { Plot area } \\
\text { (x repetition) }\end{array}$ & $\begin{array}{c}\text { Sowing } \\
\text { date } \\
\text { (dd/mm) }\end{array}$ & Duration & $\begin{array}{l}\text { Fertilization } \\
\quad\left(\mathrm{kg} \mathrm{ha}^{-1}\right)\end{array}$ & $\begin{array}{c}\text { Manual } \\
\text { weed } \\
\text { control }\end{array}$ & $\begin{array}{c}\text { Trial } \\
\text { ID }\end{array}$ \\
\hline \multirow{8}{*}{ 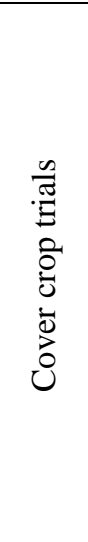 } & \multirow{6}{*}{ La Mare } & \multirow{6}{*}{-20.9} & \multirow{6}{*}{55.53} & \multirow{6}{*}{$50 \mathrm{~m}$} & \multirow{6}{*}{ Nitisol } & 2016 & 23.0 & 31 & \multirow{3}{*}{$16 \mathrm{~m}^{2}(\mathrm{x} 1)$} & $30 / 03$ & $\begin{array}{c}3.5 \\
\text { months }\end{array}$ & NPK (36-82-60) & \multirow{8}{*}{$\stackrel{\infty}{\Delta}$} & 1 \\
\hline & & & & & & 2017 & 23.2 & 28 & & $13 / 04$ & 4 months & \multirow{2}{*}{ no } & & 2 \\
\hline & & & & & & 2018 & 22.7 & 26 & & $27 / 04$ & 4 months & & & 3 \\
\hline & & & & & & \multirow{3}{*}{2018} & 25.7 & \multirow{3}{*}{15} & \multirow{3}{*}{$12 \mathrm{~m}^{2}(\mathrm{x} 1)$} & $20 / 02$ & \multirow{3}{*}{3 months } & \multirow{3}{*}{ no } & & \multirow{3}{*}{4} \\
\hline & & & & & & & 22.0 & & & $12 / 04$ & & & & \\
\hline & & & & & & & 23.6 & & & $13 / 06$ & & & & \\
\hline & $\begin{array}{c}\text { Bassin } \\
\text { Plat }\end{array}$ & -21.32 & 55.49 & $160 \mathrm{~m}$ & $\begin{array}{c}\text { Andic } \\
\text { Cambisol }\end{array}$ & 2016 & 24.0 & 18 & $16 \mathrm{~m}^{2}(\mathrm{x} 1)$ & $04 / 03$ & \multirow{2}{*}{$\begin{array}{c}2.5 \\
\text { months }\end{array}$} & \multirow{2}{*}{ NPK (36-77-48) } & & 5 \\
\hline & Colimaçon & -21.13 & 55.3 & $800 \mathrm{~m}$ & $\begin{array}{c}\text { Andic } \\
\text { Cambisol }\end{array}$ & 2016 & 20.5 & 18 & $16 \mathrm{~m}^{2}(\mathrm{x} 1)$ & $16 / 03$ & & & & 6 \\
\hline \multirow{4}{*}{ 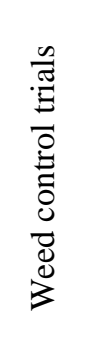 } & \multirow{3}{*}{ 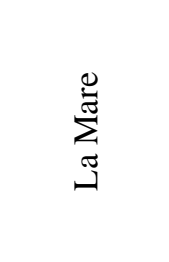 } & \multirow{3}{*}{-20.9} & \multirow{3}{*}{55.53} & \multirow{3}{*}{$50 \mathrm{~m}$} & \multirow{3}{*}{ Nitisol } & 2016 & 24.1 & $6(+9)$ & $36 \mathrm{~m}^{2}(\mathrm{x} 1)$ & $04 / 04$ & \multirow{4}{*}{2 months } & NPK (30-80-60) & \multirow{4}{*}{ 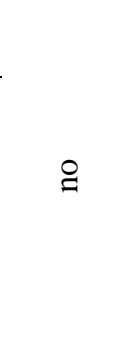 } & 7 \\
\hline & & & & & & 2016 & 24.4 & 8 & $100 \mathrm{~m}^{2}(\mathrm{x} 1)$ & $31 / 03$ & & & & 8 \\
\hline & & & & & & 2017 & 24.2 & $6(+6)$ & $20 \mathrm{~m}^{2}(\mathrm{x} 4)$ & $13 / 04$ & & no & & 9 \\
\hline & $\begin{array}{c}\text { Bassin } \\
\text { Plat }\end{array}$ & -21.32 & 55.49 & $160 \mathrm{~m}$ & $\begin{array}{c}\text { Andic } \\
\text { Cambisol }\end{array}$ & 2017 & 25.3 & $4(+3)$ & $24 \mathrm{~m}^{2}(\mathrm{x} 4)$ & $03 / 03$ & & & & 10 \\
\hline
\end{tabular}


In addition to cover crop traits, in the weed control trials, we assessed two weed control efficiency indices in terms of weed ground cover $\left(\mathrm{WCE}_{\mathrm{COV}}\right)$ and biomass $\left(\mathrm{WCE}_{\mathrm{DM}}\right)$. Like for cover crop traits, a mean ground cover index for weed over time (COV weed) was calculated in each plot in each trial. Then for each plot containing cover crops, we assessed the $\mathrm{WCE}_{\mathrm{COV}}$ as follows:

$$
W C E_{\text {COV }}=1-\frac{C O V_{W e e d, c c}}{<C O V_{\text {Weed,pure }}>}
$$

where $\mathrm{COV}_{\text {Weed,cc }}$ is the mean ground cover by weeds in plots with cover crops and $<\mathrm{COV}_{\text {Weed,pure }}>$ is the average $\mathrm{COV}_{\text {Weed }}$ in control plots (pure weeds) in each trials. Similarly, the $\mathrm{WCE}_{\mathrm{DM}}$ was calculated based on final weed dry mass (DMweed) in control plots and in plot planted with cover crops:

$$
W C E_{D M}=1-\frac{D M_{W e e d, c c}}{<D M_{\text {Weed,pure }}>}
$$

where $\mathrm{DM}_{\text {Weed,cc }}$ is the aboveground weed dry mass in plots with cover crops and 〈DM $\left.\mathrm{Deed}_{\text {,pure }}\right\rangle$ is the average aboveground weed dry mass in control plots in each trials. All experimental data are available online on CIRAD dataverse (http://dx.doi.org/10.18167/DVN1/HA0V2G).

Table 2. Traits and variables measured in the trials and used in the study. The identification of each trial (Trial ID) in which measurements were made is given. 0-1 indicates that the variable values ranged

\begin{tabular}{|c|c|c|c|c|}
\hline & Index & Units & Description & Trial ID \\
\hline \multirow{8}{*}{ 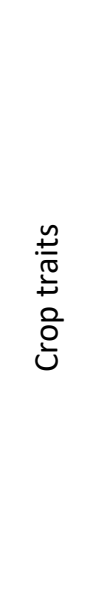 } & COV $_{\text {MEAN }}$ & $\%$ & Mean ground cover & All trials \\
\hline & COV RATE & $\% d^{-1}$ & $\begin{array}{l}\text { Rate of increase in ground cover per day between sowing } \\
\text { and maximum cover }\end{array}$ & All trials \\
\hline & $\mathrm{COV}_{\text {MAX }}$ & $\%$ & Maximum ground cover & All trials \\
\hline & HRATE & $\mathrm{cm} \mathrm{d}^{-1}$ & $\begin{array}{l}\text { Rate of increase in height per day from emergence to } \\
\text { maximum height }\end{array}$ & $1,2,4,5,6,9,10$ \\
\hline & Leaf $_{\text {RATE }}$ & leaf $d^{-1}$ & Leaf appearance rate per day & $1,2,4,5,6,9,10$ \\
\hline & EmergSDD & ${ }^{\circ} \mathrm{d}$ & Thermal time for emergence since planting & $1,2,5,6$ \\
\hline & FlosdD & ${ }^{\circ} \mathrm{d}$ & Thermal time for flowering since planting & $1,2,5,6$ \\
\hline & $A B V_{D M}$ & $\mathrm{kgDM} \mathrm{m}^{-2}$ & Aboveground dry mass at the end of the trial & 9,10 \\
\hline \multirow{2}{*}{ 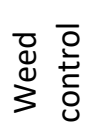 } & WCEcov & $0-1$ & Weed control efficiency index based on weed cover & $7,8,910$ \\
\hline & WCEDM & $0-1$ & Weed control efficiency index based on weed dry mass & 9,10 \\
\hline
\end{tabular}
from 0 to 1. 


\subsection{Data analyses}

First, we tested for a bias in the $\mathrm{COV}_{\text {MEAN }}$ and $\mathrm{COV}_{\mathrm{RATE}}$ data in the cover crop trials between the different factors tested in this study (Supplementary Information B, Table B1): location of the site, average daily temperature ( $\mathrm{T}_{\mathrm{MEAN}}$ ), fertilization regime, cover crop genus, family, area of origin, life cycle and growth habit (Chi-square test using the chisq.test $\mathrm{R}$ function). A variance analysis based on a mixed linear model was performed on cover crop traits using the crop life cycle and the combined crop family $\mathrm{x}$ area of origin as fixed effects and the trial identification as random effect (R package nlme, Pinheiro et al., 2020). To ensure the normality of residues, all crop traits were transformed using the Box-Cox power transformation ( $R$ package MASS, Venables and Ripley 2002). Then a post hoc analysis on crop traits were done using the non-parametric Dunn test with respect to area of origin, life cycle and family ( $R$ package dunn.test, Dinno 2017). A variance analysis based on a mixed linear model was also performed on $\mathrm{WCE}_{\mathrm{COV}}$ and $\mathrm{WCE}_{\mathrm{DM}}$ using the crop mixture type and the combined crop family $\mathrm{x}$ area of origin as fixed effects, separately, each time with the trial identification as random effect. Post hoc analyses on weed control efficiencies were done using the non-parametric Dunn test. Finally, correlations between individual traits were assessed with a Spearman correlation ( $\rho_{\text {SPEAR, }}$ R package Hmisc, Harrell et al., 2020 and corrplot, Wei and Simko, 2017) on all individual data points, without taking into account for site or species. For visual purposes, polynomial smooth regressions were added in the figures using the loess R function. Additional packages were used for plotting (ggplot2, Wickham, 2016 and ggrepel, Slowikowski, 2020). All data analyses were performed with R 4.0 (R Development Core Team, 2020).

\section{Results}

\subsection{Analyses of bias in the cover crop trials}

Due to the unbalanced design, possible biases related to the pedo-climatic contexts as well as to the choice of genus studied were assessed. No bias was found between the location of the site, average temperature and the genus, family, area of origin, life cycle and growth habit of the cover crops (Table B1), except for a small bias between the area of origin and $\mathrm{T}_{\text {MEAN }}$ (with $62 \%$ of tropical cover crops grown at $23{ }^{\circ} \mathrm{C}$ versus $51 \%$ for temperate species, Table B2). On the contrary, the fertilization regime introduced a bias in the analyses notably in the area of origin and family of the cover crop (Table B3). In the same site (La Mare) but in different years, $\mathrm{COV}_{\text {MEAN }}$ was higher in trials with no fertilization than in trial including fertilization at the level of the cover crop species (Fig. B1), highlighting the fact climate played a more important role in driving the growth of cover crops than fertilization in our trials. A strong bias was also observed between cover crop growth habits and other factors such as the genus, family, area of origin or life cycle of the cover crop (Table B1). In particular, all vines and creeping species were Fabaceae whereas erect species were found in all families, including Fabaceae (Table B4). Consequently, the growth habit factor could not be tested independently of all other factors, even within Fabaceae. 


\subsection{Ground cover dynamics in the cover crop trials}

The performance of cover crops varied greatly depending on the genus of the cover crop (Fig. 1). $C_{\text {MEAN }}$ ranged from $10 \%$ to $60 \%$, and $C_{\text {RATE }}$ ranged from $0.2 \% \mathrm{~d}^{-1}$ to $1.7 \% \mathrm{~d}^{-1}$ on average. Even if these two traits were linearly correlated $(r=0.84, n=34, p<0.0001)$, some

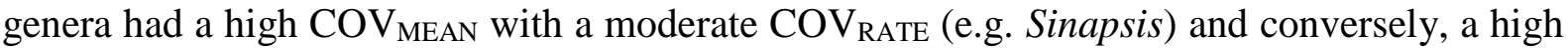

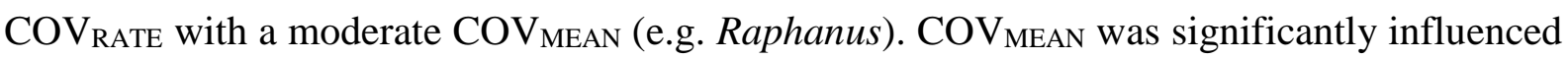
by the life cycle $\left(\mathrm{F}_{1,239}=14.9, \mathrm{p}=0.0001\right)$ and the combined crop family $\mathrm{x}$ area of origin factor $\left(F_{6,239}=3.5, p=0.0024\right.$, Table B5, Fig. 2). Area of origin had no effect on COV MEAN within the Poaceae or Fabaceae species (Fig. 2a). In temperate species, COV MEAN was higher in Asteraceae species than in Fabaceae $(\mathrm{p}=0.0134)$, and the other families were between the two. In both tropical and temperate crop species, Fabaceae and Poaceae had similar COV MEAN. $\mathrm{COV}_{\mathrm{RATE}}$ response to life cycle and combined crop family $\mathrm{x}$ area of origin was similar to COV $_{\text {MEAN }}$ (Table B5, B6; Fig. B2). Variations in other crop traits (HRATE, Leaf RATE, Emerg $_{\text {SDD }}$ and FlosDD) as a function of the family, area of origin and life cycle are detailed in Fig. B2.

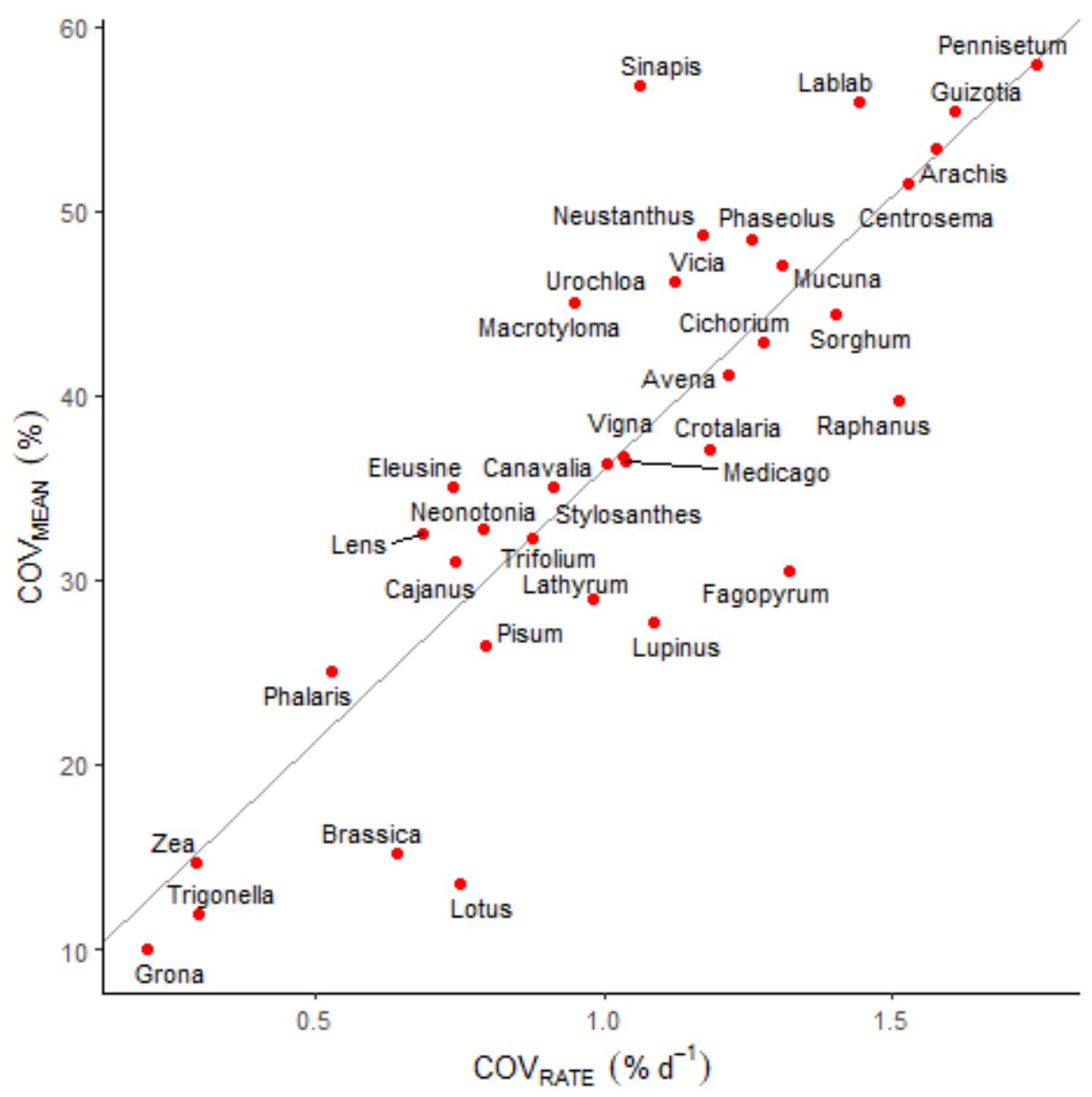

Fig. 1. Scatter plot of average mean ground cover (COV $V_{M E A N}$ \%) and rate of increase in ground cover $\left(C O V_{R A T E}, \% d^{-1}\right)$ of the cover crop genus in the six cover crop trials. Each point is associated with the name of the genus concerned. The gray line represents the regression line. 
(a)

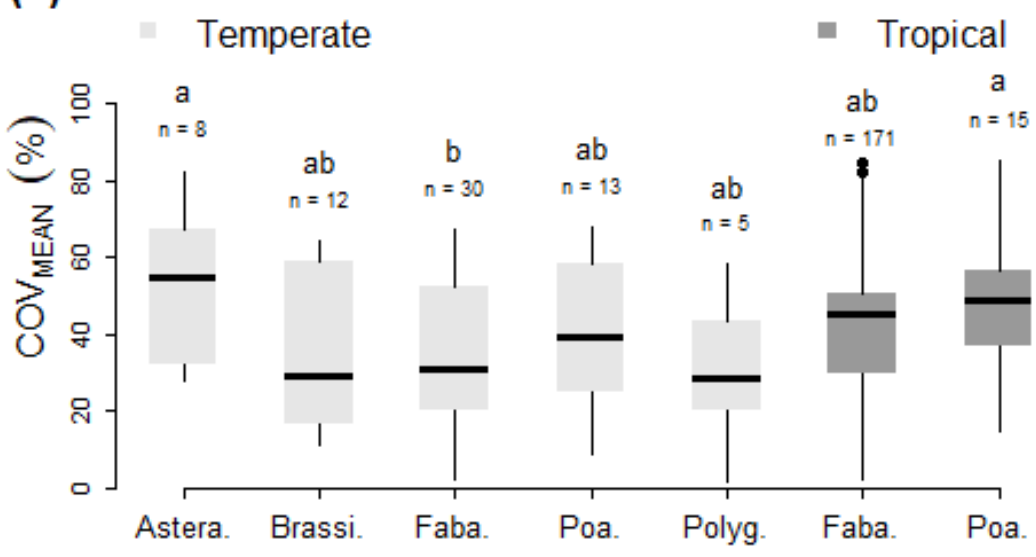

(b)

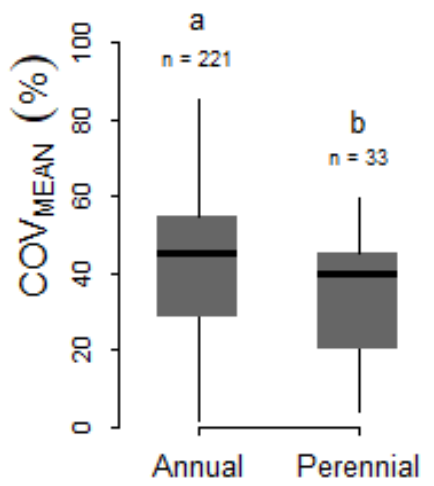

Fig. 2. Mean ground cover (COV $\left.V_{M E A N}\right)$ of the cover crop used in the cover crop trials depending on the crop family and area of origin (temperate or tropical) on one hand (a) and the life cycle in the other hand (annual or perennial, b). Crop families are abbreviated for Asteraceae (Astera.), Brassicaceae (Brassica.), Fabaceae (Faba.), Poaceae (Poa.) and Polygonaceae (Polyg.). The differences between combinations of factors were tested using a Dunn test and indicated by letters $a$ and $b$. The number of samples in each category is indicated by " $n$ ".

\subsection{Correlation between cover crop traits and ground cover}

Considering all cover crops (Fig. 3), a significant positive correlation was shown between the two ground cover indices $\operatorname{COV}_{\text {MEAN }}$ and $\operatorname{COV}_{\text {RATE }}\left(\rho_{\text {SPEAR }}=0.73, \mathrm{n}=254, \mathrm{p}<0.0001\right)$. Additional significant correlations were found between ground cover performance and other

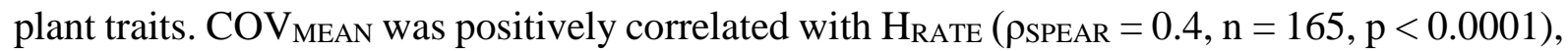
$\operatorname{Leaf}_{\text {RATE }}\left(\rho_{\text {SPEAR }}=0.33, \mathrm{n}=158, \mathrm{p}<0.0001\right)$ and FlosDD $\left(\rho_{\text {SPEAR }}=0.22, \mathrm{n}=135, \mathrm{p}=0.0114\right)$ and negatively correlated with Emerg $\operatorname{SDD}_{\text {S }}\left(\rho_{\text {SPEAR }}=-0.18, \mathrm{n}=161, \mathrm{p}=0.0210\right.$, Fig. 3). Based on a visual assessment, $\mathrm{COV}_{\text {MEAN }}$ reached its maximum values when $\mathrm{H}_{\mathrm{RATE}}>0.8 \mathrm{~cm} \mathrm{~d}^{-1}$ (Fig $3 b)$. $C_{\text {MEAN }}$ increased slightly with Leaf $f_{\text {RATE }}$ and reached maximum values when the Leaf $f_{\text {RATE }}$ was higher than 0.4 leaf $\mathrm{d}^{-1}$ (Fig 3c). The highest $\mathrm{COV}_{\text {RATE }}$ was also found when EmergSDD was less than $150^{\circ} \mathrm{d}$ (Fig. 3d). Other significant correlations found between plant traits are shown in Fig. 3a. FlosDD was highly correlated with Leaf RATE $_{\text {( }} \rho_{\text {SPEAR }}=0.47, n=96$, $\mathrm{p}<0.0001)$ and less with Emerg $_{\text {SDD }}\left(\rho_{\text {SPEAR }}=0.33, \mathrm{n}=136, \mathrm{p}<0.0001\right)$. Leaf $f_{\text {RATE }}$ and $\mathrm{H}_{\text {RATE }}$ were slightly but significantly correlated $\left(\rho_{\text {SPEAR }}=0.26, \mathrm{n}=153, \mathrm{p}=0.0014\right)$. The correlations between ground cover variables and $\mathrm{H}_{\mathrm{RATE}}$ were still significant when only Fabaceae species or non-Fabaceae cover crops were considered (Fig. B3). Nonetheless, Leaf RATE $_{\text {and FlosDD were }}$ positively correlated with $\mathrm{COV}_{\text {MEAN }}$ in Fabaceae crops $\left(\rho_{\text {SPEAR }}=0.5, \mathrm{n}=122, \mathrm{p}<0.0001\right.$ and $\rho_{\text {SPEAR }}=0.29, \mathrm{n}=120, \mathrm{p}=0.0015$, respectively) but no correlations were found in non-Fabaceae crops (Fig. B3). 
(a)

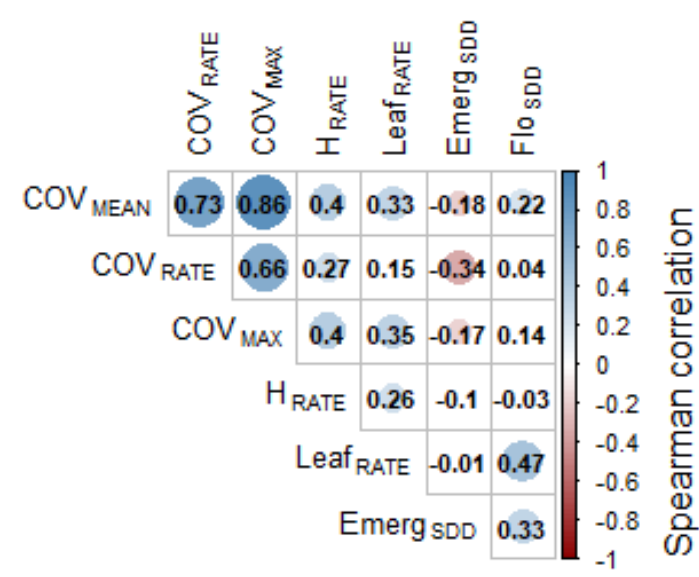

(c)

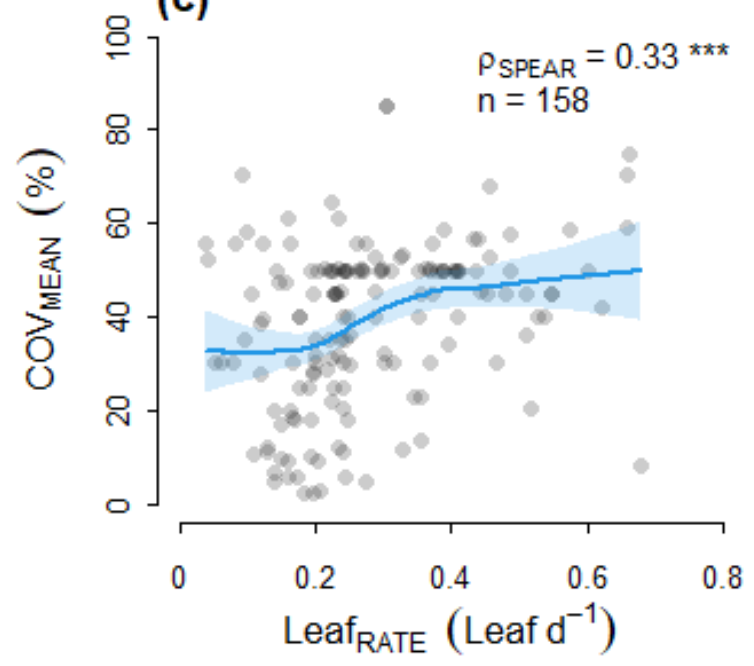

(b)

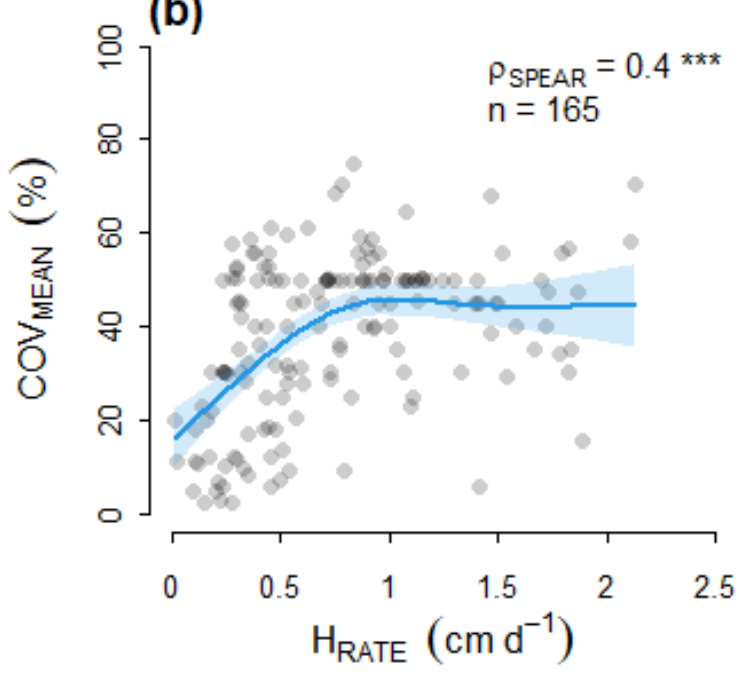

(d)

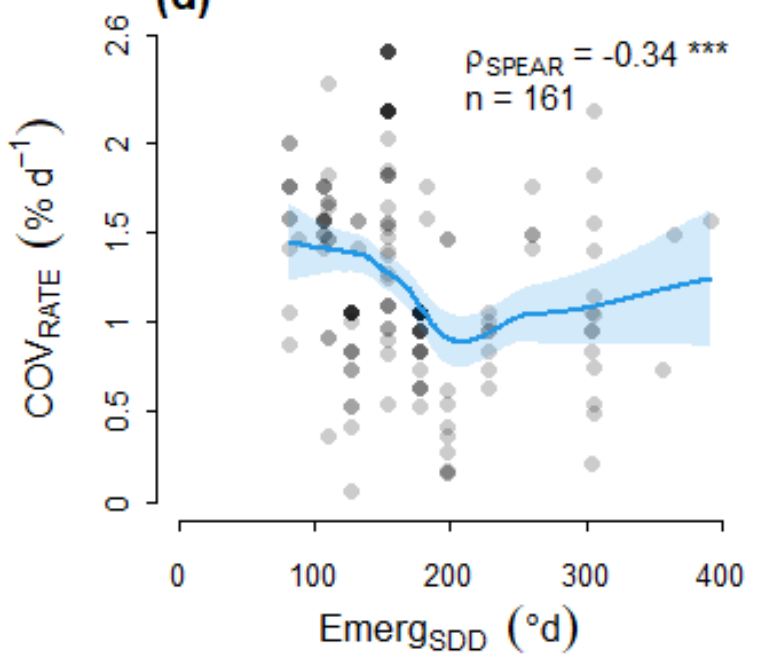

Fig 3. Spearman correlation ( $\left.\rho_{S P E A R}\right)$ between cover crop traits in the cover crop trials $(a)$. Significant positive and negative correlations are in blue and red circles, respectively. Relations between mean ground cover $\left(C O V_{M E A N}\right)$ and rate of increase in height $\left(H_{R A T E}\right)$ and leaf appearance rate (Leaf $\left.f_{R A T E}\right)$ are detailed in $(b)$ and $(c)$. The relation between the rate of increase in ground cover (COV $\left.V_{R A T E}\right)$ and thermal time for emergence (Emerg ${ }_{S D D}$ ) is presented in (d). In each case, the number of samples is indicated ( $n$ ) and a smooth regression was added using a polynomial smooth regression (blue line) with confidence interval (area shaded in light blue). 


\subsection{Weed control by pure versus mixed cover crops}

Considering both pure and mixed stand, weed control efficiency indices based on weed cover (WCE $\left.E_{C O V}\right)$ and dry mass $\left(W_{D C}\right)$ were linearly correlated $(r=0.67, n=39, p<0.0001)$. No difference in mean $\mathrm{WCE}_{\mathrm{COV}}$ and $\mathrm{WCE}_{\mathrm{DM}}$ were found between pure and mixed stands of cover crop (Table B7, Fig. 4a, Fig. B4a). Nonetheless, variance in WCEDM was significantly lower in mixed stands than in pure stands ( $\mathrm{sd}=0.17$ and 0.35 , in pure and mixed stands respectively, $\mathrm{F}_{15,27}=0.24$, p-value $\left.=0.006\right)$ but no statistical difference was found for $\mathrm{WCE}_{\mathrm{COV}}(\mathrm{sd}=0.20$ and 0.27 , respectively, $\left.\mathrm{F}_{25,44}=0.59, \mathrm{p}=0.155\right)$. In pure crops, $\mathrm{WCE}_{\mathrm{COV}}$ and $\mathrm{WCE}_{\mathrm{DM}}$ were significantly influenced by the combined area of origin and crop family factor (Table B7, p = 0.0001). In temperate species, WCE $E_{C O V}$ was higher in pure stand with Asteraceae species than Fabaceae species (Fig. 4b, Table B8, $\mathrm{p}=0.0136$ ), similarly to $\mathrm{WCE}_{\mathrm{DM}}$ (Fig. B4). In tropical species, WCE $\mathrm{COv}$ was higher in pure stand with Poaceae species than Fabaceae species (Fig. 4b, Table B8, $p=0.0002$ ), similarly to $\mathrm{WCE}_{\mathrm{DM}}$ (Fig. B4). No difference in weed control were found between tropical and temperate species within crop family. The cover crops with the

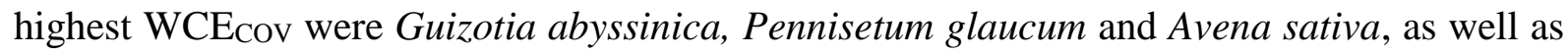
mixtures including these species (Fig. 4c). On the contrary, Stylosanthes guianensis, Raphanus sativus and Crotalaria juncea and mixtures including these species had low WCE $\mathrm{WOV}_{\text {. Other }}$ species such as Canavalia ensiformis, Vicia villosa and Vigna unguiculata displayed intermediate weed control efficiency. Due to the high variability of weed control efficiency among cover crops, we have found no significant correlation between the level of infestation (weed cover or weed dry mass) in the neighboring control plots and weed control efficiency (WCE $\mathrm{WOv}_{\mathrm{C}}$ or $\mathrm{WCE}_{\mathrm{DM}}$ ). 
(a)

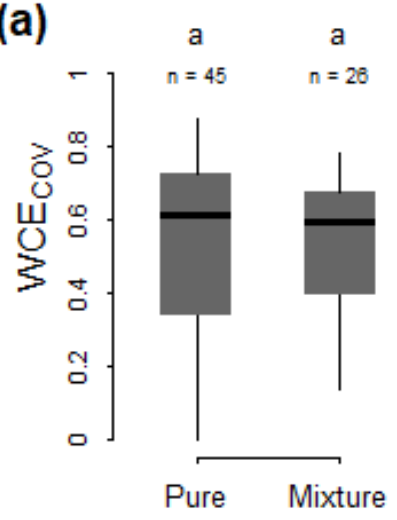

(b)
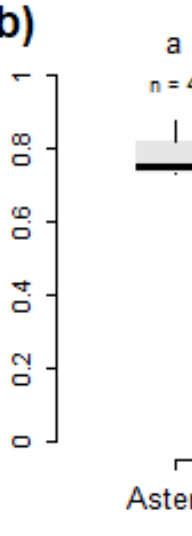

Temperate

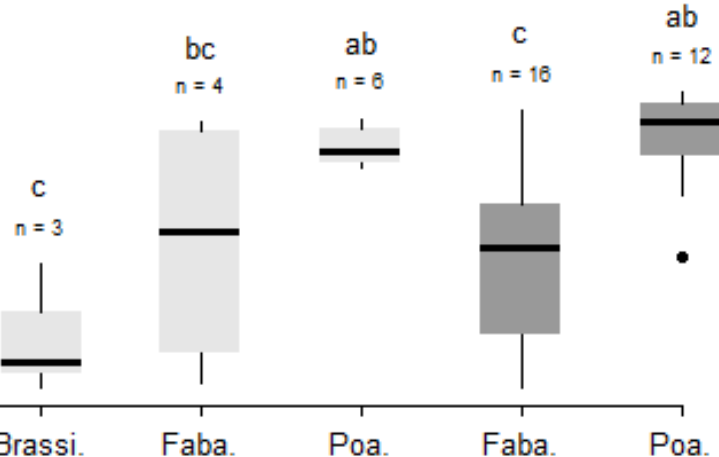

(c)

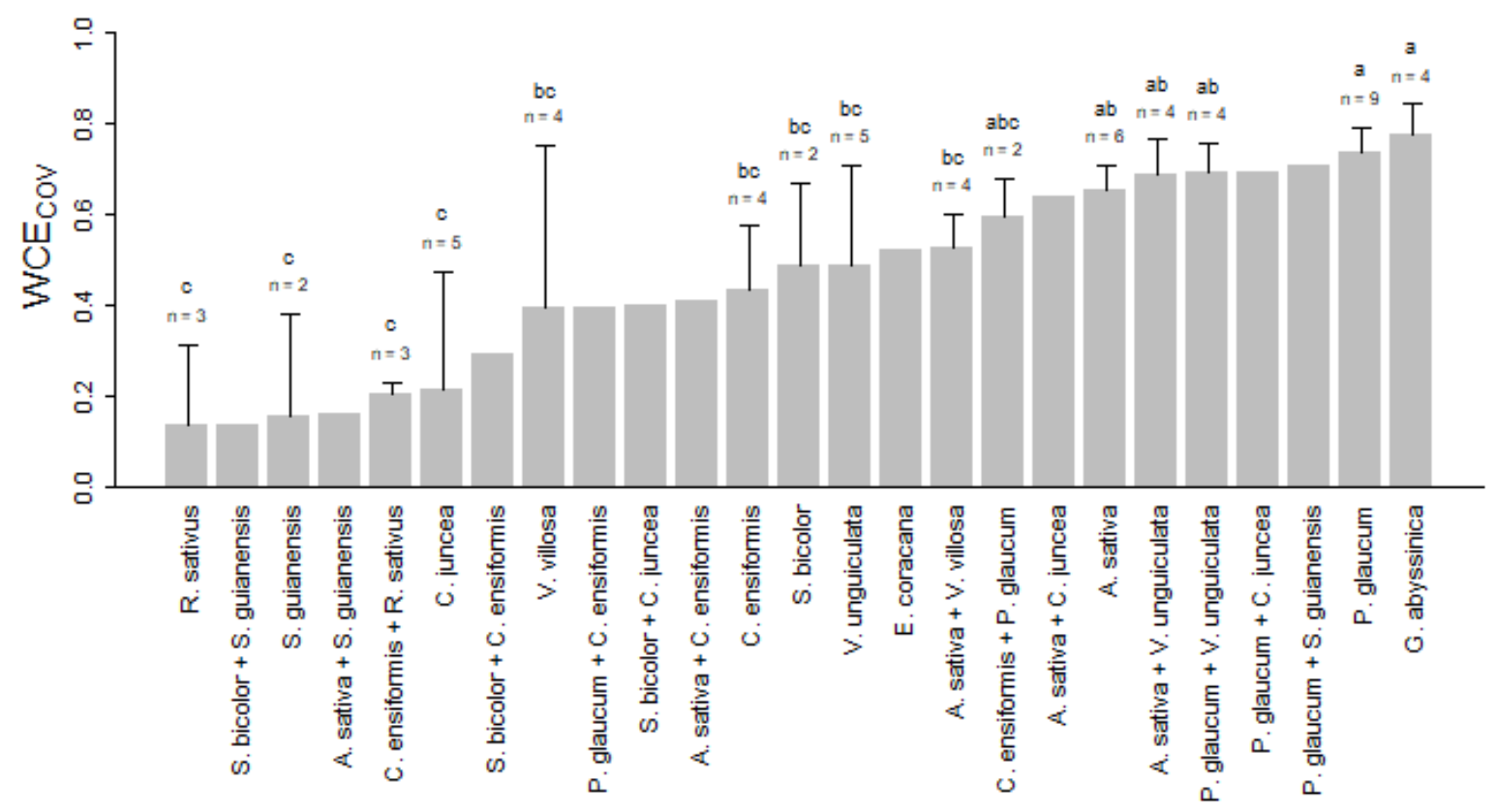

Fig. 4. Weed control efficiency in terms of weed cover (WCE $\left.E_{\mathrm{COV}}\right)$ in pure cover plots or a mixture of two cover crops (a), depending on crop family and area of origin in pure plots (b) or depending on cover crop species (c) in the four weed control trials. Crop families are abbreviated for Asteraceae (Astera.), Brassicaceae (Brassica.), Fabaceae (Faba.) and Poaceae (Poa.). The difference between factors was tested using Dunn's test and is indicated by letters $a, b$ and $c$. The number of samples in each category is indicated by " $n$ ". When cover crop plots were repeated in (c), standard error was added. 


\subsection{Weed control and crop traits}

In pure stands, $W_{C E}$ Cov was positively correlated with $\operatorname{COV}_{\text {MEAN }}\left(\rho_{S P E A R}=0.78, p=0.0002\right)$, $\operatorname{COV}_{\text {RATE }}\left(\rho_{\text {SPEAR }}=0.40, \mathrm{p}<0.0001\right), \operatorname{COV}_{\text {MAX }}\left(\rho_{\text {SPEAR }}=0.78, \mathrm{p}=0.0003\right)$ as well as $\mathrm{H}_{\text {RATE }}$ $\left(\rho_{\text {SPEAR }}=0.50, \mathrm{p}=0.0001\right)$ and $\mathrm{ABV}_{\mathrm{DM}}\left(\rho_{\text {SPEAR }}=0.63, \mathrm{p}<0.0001\right.$, Fig. 5$)$. Similar correlations were found for WCE $\mathrm{DM}_{\mathrm{DM}}$ (Fig. B5). The crop trait with the highest correlation with WCEDM was $\operatorname{COV}_{\text {RATE }}\left(\rho_{\text {SPEAR }}=0.83, \mathrm{n}=20, \mathrm{p}<0.0001\right.$, Fig. B5). On the contrary, correlations between weed control efficiency and leaf appearance rate were not significant.

(a)

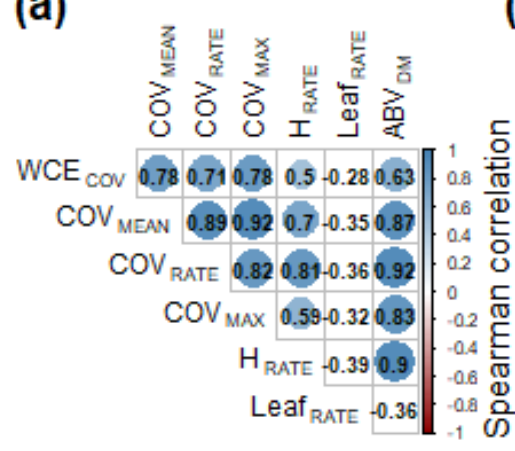

(b)

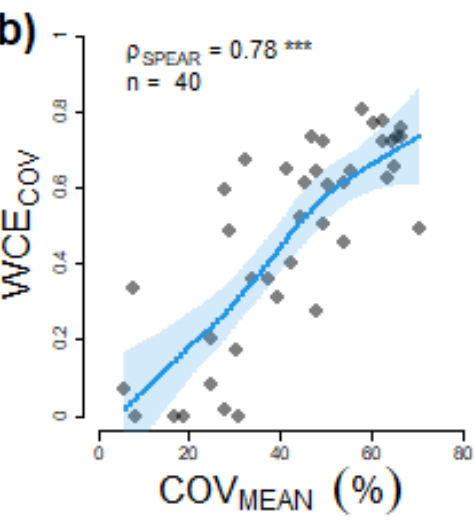

(d)

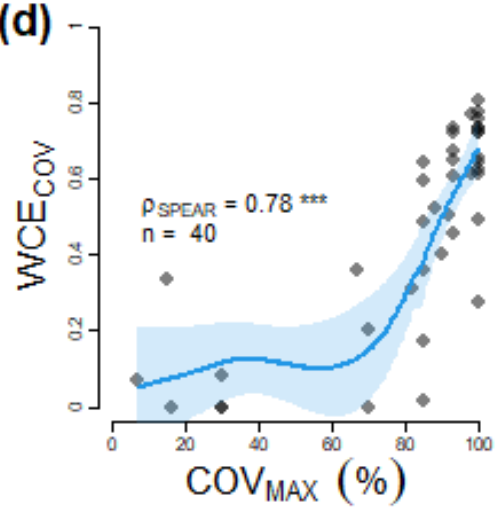

(e)

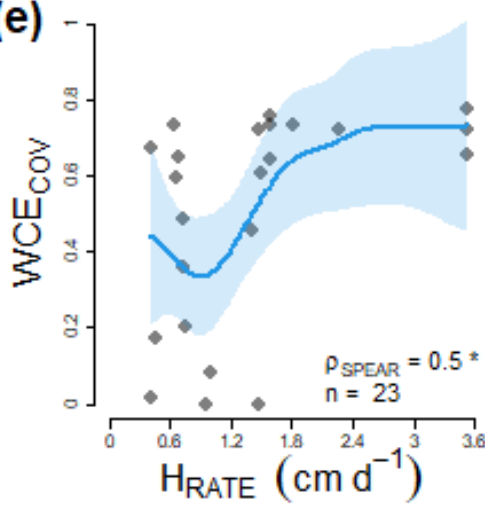

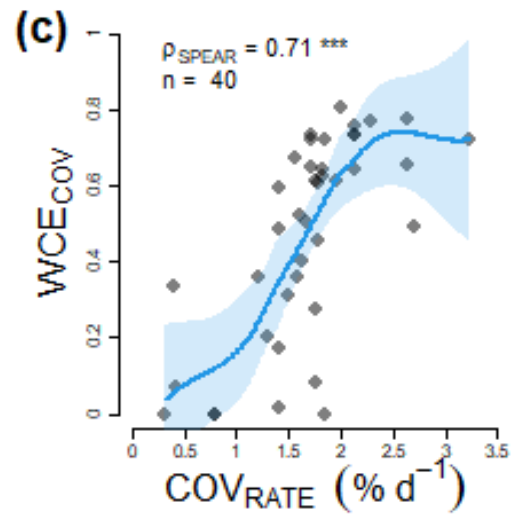

(f)

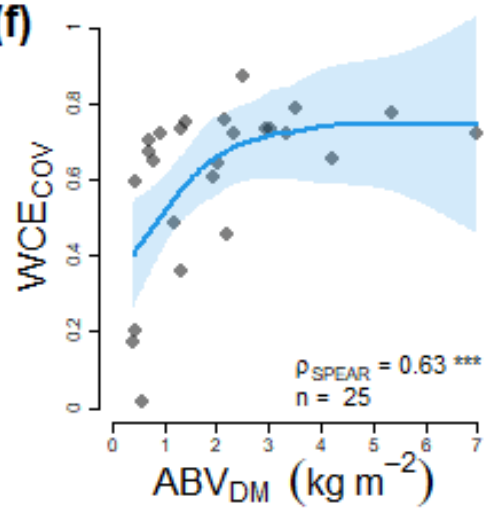

Fig. 5. Spearman correlation between cover crop traits in pure stand in the weed control trials (a). Significant positive and negative correlations are in blue and red circles, respectively. Change in weed control efficiency based on weed cover (WCE $\left.E_{C O V}\right)$ in pure crops depending on cover crop traits: mean ground cover (COV $\left.V_{M E A N}, b\right)$, rate of increase in ground cover (COV RATE, $c)$, maximum ground cover $\left(C O V_{M A X}, d\right)$, rate of increase in height $\left(H_{R A T E}, e\right)$ and aboveground dry mass $\left(A B V_{D M}, f\right)$ are detailed. The number of samples $(n)$ and the Spearman correlation coefficient $\left(\rho_{S P E A R}\right)$ are indicated. Polynomial smooth regression between weed control and crop traits were added (blue line) with confidence interval (area shaded in light blue). 


\section{Discussion}

\subsection{Study bias and limits}

Due to the particular design of the study, our results need to be evaluated taking into account possible biases related to the pedo-climatic contexts as well as to the choice of species studied. Although the location of the study site and temperature caused little systematic bias at the scale of the categories studied, conclusions concerning species should be limited to species found in all three study sites. Further, as is true in any site-specific study, here species performance is linked to the pedo-climatic context in Reunion Island. Despite the fact that the fertilization regime introduced a bias in the analyses, species comparison at the same site with or without fertilization suggest that climate played a more important role in the growth of cover crops than fertilization. Additionally, the majority of cover crops studied in the cover crop trials were Fabaceae $(n=208)$ compared to other crop families $(n=55)$. This imbalance could bias the correlations found between plant traits and ground cover dynamics. Nonetheless, the majority of correlations remained unchanged when only Fabaceae crops or non-Fabaceae crops were considered (e.g. HRATE and COV $\mathrm{V}_{\text {MEAN }}$ ) except for the relation between ground cover and Leaf RATE and FlosDD.

\subsection{Cover crop performance and weed control}

The increasing interest of producers and researchers in cover crops may have been encouraged by the many positive aspects attributed to cover cropping such as improving soil fertility and controlling pests, weeds and erosion (Altieri et al., 2011; Kocira et al., 2020; Koohafkan et al., 2012; Snapp et al., 2005). In particular, cover crops provide direct weed control during their establishment by competing with weeds for light, water, nutrients and space (Blanco-Canqui et al., 2015), as well as releasing allelochemical compounds into the environment (Farooq et al., 2011). Additionally, cover crop residues left on the soil surface can directly limit the germination and growth of weeds in the following cash crop (Mirsky et al. 2011; Ryan et al. 2011; Teasdale and Mirsky 2015). Most importantly, they can help prevent the buildup of weed plant populations thereby reducing future weed pressure.

In intensive tropical agrosystems, the hypothesis of competition particularly for light is mainly put forward in weed regulation as the other resources are seldom limiting for plant growth (high fertilization rates, high rainfall or irrigation). As a consequence, in this study we chose to focus on the rate of increase in ground cover $\left(\mathrm{COV}_{\mathrm{RATE}}\right)$ to identify species with early canopy closure and the mean ground cover over time (COV MEAN) to optimize ground cover over many months. Our results showed that weed control by cover crops was improved using species with a high ground cover rate at the beginning of the growth (COV $\left.\mathrm{RATE}_{\mathrm{H}}\right)$ and high ground cover over time (COV $\left.\mathrm{CEAN}_{\mathrm{M}}\right)$. These observations confirm previous reports that species with early canopy closure generally show better weed suppression (Baraibar et al., 2018; Hayden et al., 2012). Additionally, in our study, cover crops with higher biomass also controlled weeds better, underlining the role of competition for resources. High biomass production can increase the effect of competition (den Hollander et al., 2007; Tobin et al., 2012) and many studies have 
highlighted the relation between cover crop biomass and weed control (e.g. Bhaskar et al., 2018; Florence et al., 2019; Osipitan et al., 2019; Schappert et al, 2019). Nevertheless, cover crop biomass is not always a good predictor of weed control (Baraibar et al., 2018; Kunz et al., 2016) and some authors like Dorn et al. (2015) suggest that rapid plant development after sowing is more important than the final biomass. The results of our study do not allow us to disentangle the effect of early canopy closure (COV RATE) and biomass, because the two traits were highly correlated and the correlations with weed control were similar in both cases. Nonetheless, our results suggest that early canopy closure must reach a threshold to effectively control weeds.

Some authors suggest that increased cover crop diversity results in greater weed suppression (Akemo et al. 2000; Brennan and Smith 2005; Lawson et al. 2015), while others are more nuanced (Baraibar et al., 2018; Finney et al., 2016; Florence and McGuire, 2020; Schappert et al., 2019; Smith et al., 2014). In our study, average weed control efficiency by pure and mixed cover crop species was similar. Nevertheless, the standard deviation of weed control by pure cover crops was larger than the one of mixtures when considering weed biomass. In particular, depending on the species, a single cover crop might not be able to buffer rapidly changing environmental conditions (Wendling et al., 2019). Therefore, many studies have investigated the adaptability of mixtures (Hajjar et al., 2008; Tilman et al., 2001). On average in the literature, mixtures were shown to be less effective than the most efficient single sown cover crops (e.g. Smith et al., 2020). Nevertheless, combinations of species may increase resilience against weather conditions, which is an advantage in achieving efficient long-term weed control (Lawson et al. 2015).

When aiming to identify cover crop species adapted to new environments, assessing the efficiency of weed control may be challenging if a wide range of cover crops and mixtures is used, particularly due to the variability of plant performance related to soil and climate variability. However, plant traits could be considered as indicators of plant-driven processes thus making it possible to compare wide ranges of cover crops. In the current study, many crop traits were correlated with weed control efficiency but also with each other. Among them, the maximum ground cover was highly correlated with both mean ground cover over time and weed control efficiency. Being easy to measure, it is therefore a relevant trait to compare wide ranges of species under similar tropical conditions than Reunion Island.

\subsection{Plant traits and weed control}

Trait-based approaches have a high potential to identify the most suitable cover crops and traits to control weeds (Damour et al., 2018). To use-the terminology of Tardy et al. (2015), crops that invest carbohydrates in a support structure to grow in height have a "shading" competition strategy, with no physical action on neighbours. Their ability to develop support structures in height allows them to be in the top layers of the canopy, and therefore to have increased access to light and to shade neighboring plants (Garnier and Navas, 2012). This strategy is illustrated by $\mathrm{H}_{\mathrm{RATE}}$ in our study. On the contrary, plants that invest in leaf production (Leaf RATE$_{\text {) }}$ with rapid growth $\left(\mathrm{COV}_{\mathrm{RATE}}\right)$ can be either creeping or vine species. They have an "obstruction" 
competition strategy conferred by their ability to cover the soil and to avoid the germination and the emergence of weeds. Vine species can also smother weeds but also the main crop (Teasdale 1998). In our study, all vines and creeping crops were Fabaceae and $85 \%$ of Fabaceae were vines or creeping crops. In our study, Fabaceae crops tend to have an obstruction strategy

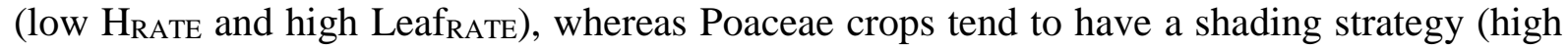
$\mathrm{H}_{\text {RATE }}$ and low Leaf $f_{\text {RATE}}$. While all species with high ground cover and biomass succeeded in controlling weeds, our results suggest that, in our tropical conditions, the 'shading' strategy is more efficient than the 'obstruction' strategy. Indeed, although Leaf $f_{\text {RATE }}$ is a good indicator of ground cover among Fabaceae crops, we found no link with weed control. In temperate conditions, it has also been observed that tall grasses (Poaceae) like cereals are highly weed suppressive due to their rapid growth rate (Brennan and Smith, 2005; Dorn et al., 2015; Finney et al., 2016; Hayden et al., 2012). However, this comparison requires further investigation because Leaf RATE alone is not enough to identify an 'obstruction' strategy and but needs to be completed by other traits such as specific leaf area or leaf area to mass ratio (Damour et al., 2014; Tardy et al., 2015).

Previous studies reported that Poaceae were often more efficient in controlling weeds than Fabaceae legume species (Baraibar et al., 2018; Brainard et al., 2011; Ofori and Stern, 1987), in agreement with our results. Nevertheless, the ground covering ability of Poaceae and Fabaceae species was similar in our study, suggesting other mechanisms are involved in weed control. The limited weed control displayed by Fabaceae could also be explained by low competition for soil resources. Legumes are $\mathrm{N}_{2}$-fixing species known to have less developed roots than grasses and cereals (Corre-Hellou et al., 2007; Greenwood et al., 1982; ThorupKristensen, 2001). While root traits are the subject of increasing study in cover crops (Fort et al., 2012; Roumet et al., 2006; Tardy et al., 2017, Wendling et al., 2016), there is still a need to better understand the relation between soil resource-acquisition strategies and weed control. Moreover, our results also shown that the inter-specific variability of crop traits or weed control is remarkably high within crop family, highlighting how the identity of the species will determine its performance, in comparison to crop origin or family.

\subsection{Cover crops in Reunion Island}

While the use of species with shading competition strategies could be very efficient to control weeds in crop rotations, in intercropping systems, their ability to be in the top layer in the canopy could have detrimental effects on the yield of the main crop. In our climatic context in Reunion Island, where sugarcane is the main crop, the use of erect species with high cover and biomass, like Pennisetum glaucum, Guizotia abyssinica or Avena sativa would be particularly useful in fallow periods (3-4 months) before replanting of sugarcane. To avoid competition in the case of a sugarcane-crop association, the choice should focus on creeping or vines species that compete strongly with weeds without producing lianas (such as Vigna unguiculata and Canavalia ensiformis). As cover crop performance varies greatly with climatic conditions and management practices (Osipitan et al., 2020), the species we chose in this study will only be valid in similar climatic areas. Nevertheless, the selection of traits that improve weed control 
should not depend on local climatic variability, highlighting the high potential of trait-based approaches to identify the most suitable crops to control weeds.

\section{Conclusion}

Our aim was to identify cover crop species and traits that optimize ground cover and weed control in tropical agrosystems, based on a set of ten trials performed in Reunion Island. Few differences were found in ground cover depending on the life cycle or crop family, but large differences were found depending on crop species. The ability of the cover crop to cover the soil rapidly and durably increased with an increase in the height or in the leaf appearance rate (in Fabaceae species) while ground cover ability tended to decrease with thermal time for emergence. No average difference in weed control was found between pure and mixed cover crops. Nonetheless, weed control was more efficient using species with a high rate of increase in ground cover and height or a lot of aboveground biomass. While cover crops can be chosen based on traits to maximize weed control, weed traits will also influence plant-weed interactions. Consequently, the traits of the weed community should also be taken into account to choose the most suitable cover crops depending on natural flora.

\section{Author statement}

A.C. and P.M. Supervision, Project administration; P.T. and E.H. Conceptualization, Methodology, Investigation; M.C., A.N., P.V., S.A. and A.M.: Investigation, Formal analysis, Data curation; M.C. and A.N. Writing - Original Draft; All authors Writing - Review \& Editing

\section{Acknowledgements}

We thank the Conseil Régional de La Réunion, the French Ministry of Agriculture and Food, the European Union (Feader program, grant $n^{\circ} \mathrm{AG} / 974 / \mathrm{DAAF} / 2016-00096$ and Feder program, grant $n^{\circ}$ GURTDI 20151501-0000735) and Cirad for funding, within the framework of the project "Services et impacts des activités agricoles en milieu tropical" (Siaam). We are grateful to J. Fournier, T. Lizekne, R Bernard, J Courtois, MV Latchoumy, Y Marin, JM Gueno, G. Gauvin and JC Ribotte for their involvement in field measurements. 


\section{References}

Agreste, 2016. Réunion : enquête pratiques culturales canne - Le désherbage de la canne à sucre (No. 101). Daaf.

Akemo, M.C., Regnier, E.E., Bennett, M.A., 2000. Weed Suppression in Spring-Sown Rye (Secale cereale): Pea (Pisum sativum) Cover Crop Mixes. Weed Technology 14, 545-549.

Altieri, M.A., Lana, M.A., Bittencourt, H.V., Kieling, A.S., Comin, J.J., Lovato, P.E., 2011. Enhancing Crop Productivity via Weed Suppression in Organic No-Till Cropping Systems in Santa Catarina, Brazil. Journal of Sustainable Agriculture 35, 855-869. https://doi.org/10.1080/10440046.2011.588998

Antoir, J., Goebel, F.R., Le Bellec, F., Esther, J.J., Maillary, L., Mansuy, A., Marion, D., Marnotte, P., Martin, J., Rossolin, G., Vincenot, D., 2016. Les bonnes pratiques de désherbage de la canne à sucre Ile de La Réunion 2016. à sucre - lle de La Réunion 2016. C.

Baraibar, B., Hunter, M.C., Schipanski, M.E., Hamilton, A., Mortensen, D.A., 2018. Weed Suppression in Cover Crop Monocultures and Mixtures. Weed Science 66, 121-133. https://doi.org/10.1017/wsc.2017.59

Bhaskar, V., Bellinder, R.R., DiTommaso, A., Walter, M.F., 2018. Living mulch performance in a tropical cotton system and impact on yield and weed control. Agriculture (Switzerland) 8, 1-17. https://doi.org/10.3390/agriculture8020019

Blanco-Canqui, H., Shaver, T.M., Lindquist, J.L., Shapiro, C.A., Elmore, R.W., Francis, C.A., Hergert, G.W., 2015. Cover Crops and Ecosystem Services: Insights from Studies in Temperate Soils. Agronomy Journal 107, 2449-2474. https://doi.org/10.2134/agronj15.0086

Brainard, D.C., Bellinder, R.R., Kumar, V., 2011. Grass-Legume Mixtures and Soil Fertility Affect Cover Crop Performance and Weed Seed Production. Weed Technology 25, 473-479. https://doi.org/10.1614/WT-D-10-00134.1

Brennan, E.B., Smith, R.F., 2005. Winter Cover Crop Growth and Weed Suppression on the Central Coast of California1. wete 19, 1017-1024. https://doi.org/10.1614/WT-04-246R1.1

Cordeau, S., Moreau, D., 2017. Gestion des adventices au moyen des cultures intermédiaires multiservices: potentiels et limites. Innovations Agronomiques 62, 1-14.

Corre-Hellou, G., Brisson, N., Launay, M., Fustec, J., Crozat, Y., 2007. Effect of root depth penetration on soil nitrogen competitive interactions and dry matter production in pea-barley intercrops given different soil nitrogen supplies. Field Crops Res 103, 76-85. https://doi.org/10.1016/j.fcr.2007.04.008

Damour, G., Dorel, M., Quoc, H.T., Meynard, C., Risède, J.M., 2014. A trait-based characterization of cover plants to assess their potential to provide a set of ecological services in banana cropping systems. European Journal of Agronomy 52, 218-228. https://doi.org/10.1016/j.eja.2013.09.004

Damour, G., Navas, M.L., Garnier, E., 2018. A revised trait-based framework for agroecosystems including decision rules. Journal of Applied Ecology 55, 12-24. https://doi.org/10.1111/13652664.12986

den Hollander, N.G., Bastiaans, L., Kropff, M.J., 2007. Clover as a cover crop for weed suppression in an intercropping design: II. Competitive ability of several clover species. European Journal of Agronomy 26, 104-112. https://doi.org/10.1016/j.eja.2006.08.005

Dino, A., 2017. dunn.test: Dunn's Test of Multiple Comparisons Using Rank Sums. R package version 1.3.5. https://CRAN.R-project.org/package=dunn.test 
Dorn, B., Jossi, W., Heijden, M.G.A. van der, 2015. Weed suppression by cover crops: comparative on-farm experiments under integrated and organic conservation tillage. Weed Research 55, 586-597. https://doi.org/10.1111/wre.12175

FAO, 2017. Plant Production and Protection Division Integrated Weed Management [WWW Document]. fao.org. URL http://www.fao.org/agriculture/crops/thematic-sitemap/theme/spi/scpihome/managing-ecosystems/integrated-weed-management/en/.

Farooq, M., Jabran, K., Cheema, Z.A., Wahid, A., Siddique, K.H., 2011. The role of allelopathy in agricultural pest management. Pest Management Science 67, 493-506. https://doi.org/10.1002/ps.2091

Finney, D.M., White, C.M., Kaye, J.P., 2016. Biomass Production and Carbon/Nitrogen Ratio Influence Ecosystem Services from Cover Crop Mixtures. Agronomy Journal 108, 39-52. https://doi.org/10.2134/agronj15.0182

Florence, A.M., Higley, L.G., Drijber, R.A., Francis, C.A., Lindquist, J.L., 2019. Cover crop mixture diversity, biomass productivity, weed suppression, and stability. PLoS ONE 14, 1-18. https://doi.org/10.1371/journal.pone.0206195

Florence, A.M., McGuire, A.M., 2020. Do diverse cover crop mixtures perform better than monocultures? A systematic review. Agron.j. 112, 3513-3534. https://doi.org/10.1002/agj2.20340

Fort, F., Jouany, C., Cruz, P., 2012. Root and leaf functional trait relations in Poaceae species: Implications of differing resource-acquisition strategies. Journal of Plant Ecology. https://doi.org/10.1093/jpe/rts034

Garnier, E., Navas, M.-L., 2012. A trait-based approach to comparative functional plant ecology: concepts, methods and applications for agroecology. A review | SpringerLink. Agronomy for Sustainable Development 32, 365:399. https://doi.org/10.1007/s13593-011-0036-y

Greenwood, D.J., Gerwitz, A., Stone, D.A., Barnes, A., 1982. Root development of vegetable crops. Plant Soil 68, 75-96. https://doi.org/10.1007/BF02374729

Hajjar, R., Jarvis, D.I., Gemmill-Herren, B., 2008. The utility of crop genetic diversity in maintaining ecosystem services. Agriculture, Ecosystems \& Environment 123, 261-270. https://doi.org/10.1016/j.agee.2007.08.003

Harrell, F.E.J. et al., 2020. Hmisc: Harrell Miscellaneous. R package version 4.4-1. https://CRAN.Rproject.org/package=Hmisc.

Hayden, Z.D., Brainard, D.C., Henshaw, B., Ngouajio, M., 2012. Winter Annual Weed Suppression in Rye-Vetch Cover Crop Mixtures. Weed Technology 26, 818-825. https://doi.org/10.1614/WT-D-1200084.1

Kocira, A., Staniak, M., Tomaszewska, M., Kornas, R., Cymerman, J., Panasiewicz, K., Lipińska, H., 2020. Legume Cover Crops as One of the Elements of Strategic Weed Management and Soil Quality Improvement. A Review. Agriculture 10, 394. https://doi.org/10.3390/agriculture10090394

Koohafkan, P., Altieri, M.A., Gimenez, E.H., 2012. Green Agriculture: foundations for biodiverse, resilient and productive agricultural systems. International Journal of Agricultural Sustainability $10,61-$ 75. https://doi.org/10.1080/14735903.2011.610206

Korres, N.E., Froud-Williams, R.J., 2002. Effects of winter wheat cultivars and seed rate on the biological characteristics of naturally occurring weed flora. Weed Research 42, 417-428. https://doi.org/10.1046/j.1365-3180.2002.00302.x 
Kruidhof, H.M., Bastiaans, L., Kropff, M.J., 2008. Ecological weed management by cover cropping: effects on weed growth in autumn and weed establishment in spring. Weed Research 48, 492-502. https://doi.org/10.1111/j.1365-3180.2008.00665.x

Kunz, Ch., Sturm, D.J., Varnholt, D., Walker, F., Gerhards, R., 2016. Allelopathic effects and weed suppressive ability of cover crops. Plant Soil Environ. 62, 60-66. https://doi.org/10.17221/612/2015PSE

Lawson, A., Cogger, C., Bary, A., Fortuna, A.-M., 2015. Influence of Seeding Ratio, Planting Date, and Termination Date on Rye-Hairy Vetch Cover Crop Mixture Performance under Organic Management. PLoS ONE 10, e0129597. https://doi.org/10.1371/journal.pone.0129597

Lu, Y.-C., Watkins, K.B., Teasdale, J.R., Abdul-Baki, A.A., 2000. Cover crops in sustainable food production. Food Reviews International 16, 121-157. https://doi.org/10.1081/FRI-100100285

Malézieux, E., Crozat, Y., Dupraz, C., Laurans, M., Makowski, D., Rapidel, B., Tourdonnet, S.D., Mal, E., Crozat, Y., Dupraz, C., Laurans, M., Makowski, D., 2009. Mixing plant species in cropping systems : concepts, tools and models. A review To cite this version: Review article Mixing plant species in cropping systems : concepts, tools and models . Agronomy for Sustainable Development 29, 43-62. https://doi.org/10.1051/agro:2007057

Mansuy, A., Marmotte, P., Martin, J., Roux, E., Chouteau, R., Wilt, M., Soubadou, G., 2019. CanécoH : mise au point de leviers pour une Canne à sucre économe en Herbicide à La Réunion. Innovations Agronomiques 76, 103-119. https://doi.org/10.15454/tskwve

Marnotte, P., 1984. Influence des facteurs agroécologiques sur le développement des mauvaises herbes en climat tropical humide. Presented at the 7ème Coll. Int. Ecol. Biol. et Syst. des mauvaises herbes, COLUMA-EWRS, Paris, pp. 183-189.

Mathieu, B., Marnotte, P., 2000. L'enherbement des sols à Muskuwaari au Nord-Cameroun. Presented at the Eleventh international conference on weed biology, AFPP, INRA, Dijon, France, pp. 151-158.

Médiène, S., Valantin-Morison, M., Sarthou, J.-P., de Tourdonnet, S., Gosme, M., Bertrand, M., Roger-Estrade, J., Aubertot, J.-N., Rusch, A., Motisi, N., Pelosi, C., Doré, T., 2011. Agroecosystem management and biotic interactions: a review. Agronomy Sust. Developm. 31, 491-514. https://doi.org/10.1007/s13593-011-0009-1

Mennan, H., Jabran, K., Zandstra, B.H., Pala, F., 2020. Non-Chemical Weed Management in Vegetables by Using Cover Crops: A Review. Agronomy-Basel 10, 257. https://doi.org/10.3390/agronomy10020257

Mirsky, S.B., Curran, W.S., Mortenseny, D.M., Ryany, M.R., Shumway, D.L., 2011. Timing of CoverCrop Management Effects on Weed Suppression in No-Till Planted Soybean using a Roller-Crimper. Weed Science 59, 380-389. https://doi.org/10.1614/WS-D-10-00101.1

Oerke, E.C., 2006. Crop losses to pests. Journal of Agricultural Science 144, 31-43. https://doi.org/10.1017/S0021859605005708

Oerke, E.C., Dehne, H.W., 2004. Safeguarding production - losses in major crops and the role of crop protection. Crop Prot. 23, 275-285. https://doi.org/10.1016/j.cropro.2003.10.001

Ofori, F., Stern, W.R., 1987. Cereal-Legume Intercropping Systems - ScienceDirect. Advances in Agronomy 41, 41-90. 
Osipitan, O.A., Dille, A., Assefa, Y., Radicetti, E., Ayeni, A., Knezevic, S.Z., 2019. Impact of Cover Crop Management on Level of Weed Suppression: A Meta-Analysis. Crop Sci. 59, 833-842. https://doi.org/10.2135/cropsci2018.09.0589

Pester, T.A., Burnside, O.C., Orf, J.H., 1999. Increasing Crop Competitiveness to Weeds Through Crop Breeding. Journal of Crop Production 2, 59-76.

Pinheiro, J., Bates, D., DebRoy, S., Sarkar, D., R Core Team, 2020. nlme: Linear and Nonlinear Mixed Effects Models. $\mathrm{R}$ package version 3.1-148. https://CRAN.R-project.org/package=nlme.

R Development Core Team, 2020. R: A language and environment for statistical computing. $R$ Foundation for Statistical Computing, Vienna, Austria.

Ranaivoson, L., Naudin, K., Ripoche, A., Rabeharisoa, L., Corbeels, M., 2018. Is mulching an efficient way to control weeds? Effects of type and amount of crop residue in rainfed rice based cropping systems in Madagascar. Field Crops Research 217, 20-31. https://doi.org/10.1016/j.fcr.2017.11.027

Roumet, C., Urcelay, C., Díaz, S., 2006. Suites of root traits differ between annual and perennial species growing in the field. New Phytologist 170, 357-368. https://doi.org/10.1111/j.14698137.2006.01667.x

Ryan, M.R., Curran, W.S., Grantham, A.M., Hunsberger, L.K., Mirsky, S.B., Mortensen, D.A., Nord, E.A., Wilson, D.O., 2011. Effects of Seeding Rate and Poultry Litter on Weed Suppression from a Rolled Cereal Rye Cover Crop. Weed Science 59, 438-444. https://doi.org/10.1614/WS-D-10-00180.1

Schappert, A., Schumacher, M., Gerhards, R., 2019. Weed control ability of single sown cover crops compared to species mixtures. Agronomy 9. https://doi.org/10.3390/agronomy9060294

Seavers, G.P., Wright, K.J., 1999. Crop canopy development and structure influence weed suppression. Weed Research 39, 319-328. https://doi.org/10.1046/j.1365-3180.1999.00148.x

Slowikowski, K., 2020. ggrepel: Automatically Position Non-Overlapping Text Labels with 'ggplot2'. $R$ package version 0.8.2. https://CRAN.R-project.org/package=ggrepel

Smith, R.G., Atwood, L.W., Warren, N.D., 2014. Increased Productivity of a Cover Crop Mixture Is Not Associated with Enhanced Agroecosystem Services. PLOS ONE 9, e97351. https://doi.org/10.1371/journal.pone.0097351

Smith, R.G., Warren, N.D., Cordeau, S., 2020. Are Cover Crop Mixtures Better at Suppressing Weeds than Cover Crop Monocultures? wees 68, 186-194. https://doi.org/10.1017/wsc.2020.12

Snapp, S.S., Swinton, S.M., Labarta, R., Mutch, D., Black, J.R., Leep, R., Nyiraneza, J., O’Neil, K., 2005. Evaluating cover crops for benefits, costs and performance within cropping system niches. Agron. J. 97, 322-332.

Tardy, F., Damour, G., Dorel, M., Moreau, D., 2017. Trait-based characterisation of soil exploitation strategies of banana, weeds and cover plant species. PLoS ONE 12, 1-17. https://doi.org/10.1371/journal.pone.0173066

Tardy, F., Moreau, D., Dorel, M., Damour, G., 2015. Trait-based characterisation of cover plants' light competition strategies for weed control in banana cropping systems in the French West Indies. European Journal of Agronomy 71, 10-18. https://doi.org/10.1016/j.eja.2015.08.002

Teasdale, J., Brandsater, L., Calegari, A., Skora Neto, F., 2007. Cover crops and weed management, in: Non-Chemical Weed Management: Principles, Concepts and Technology. CABI, Wallingford, pp. 4964.

Teasdale, J.R., Hatfield, J.L., Buhler, D.D., Stewart, B.A., 1998. Cover crops, smother plants, and weed management. Integrated weed and soil management. 
Teasdale, J.R., Mirsky, S.B., 2015. Tillage and Planting Date Effects on Weed Dormancy, Emergence, and Early Growth in Organic Corn. Weed Science 63, 477-490. https://doi.org/10.1614/WS-D-1400112.1

Thorup-Kristensen, K., 2001. Are differences in root growth of nitrogen catch crops important for their ability to reduce soil nitrate- $\mathrm{N}$ content, and how can this be measured? Plant and Soil 230, 185195. https://doi.org/10.1023/A:1010306425468

Tilman, D., Reich, P.B., Knops, J., Wedin, D., Mielke, T., Lehman, C., 2001. Diversity and Productivity in a Long-Term Grassland Experiment. Science 294, 843-845. https://doi.org/10.1126/science.1060391

Tobin, M.F., Wright, A.J., Mangan, S.A., Schnitzer, S.A., 2012. Lianas have a greater competitive effect than trees of similar biomass on tropical canopy trees. Ecosphere 3, art20. https://doi.org/10.1890/ES11-00322.1

Vandermeer, J.H., 1992. The Ecology of Intercropping. Cambridge University Press.

Venables, W. N. and Ripley, B. D., 2002. Modern Applied Statistics with S. Fourth Edition. Springer, New York. ISBN 0-387-95457-0.

Violle, C., Navas, M.-L., Vile, D., Kazakou, E., Fortunel, C., Hummel, I., Garnier, E., 2007. Let the concept of trait be functional! Oikos 116, 882-892. https://doi.org/10.1111/j.0030-1299.2007.15559.x

Wei, T., Simko, V., 2017. R package "corrplot": Visualization of a Correlation Matrix (Version 0.84). https://github.com/taiyun/corrplot

Wendling, M., Büchi, L., Amossé, C., Sinaj, S., Walter, A., Charles, R., 2016. Influence of root and leaf traits on nutrient uptake of cover crops. Plant and Soil 409, 419-434. https://doi.org/10.1007/s11104-016-2974-2

Wendling, M., Charles, R., Herrera, J., Amossé, C., Jeangros, B., Walter, A., Büchi, L., 2019. Effect of species identity and diversity on biomass production and its stability in cover crop mixtures. Agriculture, Ecosystems \& Environment 281, 81-91. https://doi.org/10.1016/j.agee.2019.04.032

Wickham, H., 2016. ggplot2: Elegant Graphics for Data Analysis. Springer-Verlag New York. 


\section{Supplementary Information A: Complementary Material \& Methods}

Table A1. Soil characteristics in the $0-30 \mathrm{~cm}$ soil layer in the trials.

\begin{tabular}{|c|c|c|c|c|c|c|}
\hline Site & pH & $\begin{array}{l}\text { Organic C } \\
\left(\mathrm{g} \mathrm{kg}^{-1}\right)\end{array}$ & $\begin{array}{l}\text { Organic } N \\
\left(\mathrm{~g} \mathrm{~kg}^{-1}\right)\end{array}$ & $\begin{array}{l}\mathbf{P} \\
\left.(\mathbf{m g ~ k g})^{-1}\right)\end{array}$ & $\begin{array}{l}\mathrm{K} \\
\left(\mathrm{cmol}+\mathrm{kg}^{-1}\right)\end{array}$ & $\begin{array}{l}\text { CEC } \\
\left(\mathrm{cmol} \mathrm{kg}^{-1}\right)\end{array}$ \\
\hline La Mare & 6.1 & 19.0 & 1.73 & 97,5 & 0,49 & 11,7 \\
\hline Bassin Plat & 6.5 & 19.1 & 1.80 & 50.3 & 1.40 & 12.8 \\
\hline Colimaçon & 6.4 & 27.1 & 2.48 & 79.5 & 0.83 & 16.3 \\
\hline
\end{tabular}

Table A2. Weed flora in the weed control trial sites (measured in 2017).

\begin{tabular}{|c|c|c|c|}
\hline Family & Species & Bassin Plat & La Mare \\
\hline Aizoaceae & Trianthema portulacastrum $L$. & $x$ & \\
\hline Amaranthaceae & Amaranthus sp & $x$ & $x$ \\
\hline Asteraceae & Acanthospermum hispidum DC. & $x$ & \\
\hline Asteraceae & Bidens pilosa $L$. & $x$ & $x$ \\
\hline Cleomaceae & Cleome viscosa $L$. & & $x$ \\
\hline Commelinaceae & Commelina benghalensis $L$. & $x$ & \\
\hline Convolvulaceae & Ipomoea eriocarpa R.Br. & $x$ & $x$ \\
\hline Convolvulaceae & Ipomoea hederifolia $L$. & & $x$ \\
\hline Convolvulaceae & Ipomoea obscura (L.) Ker-Gawler & $x$ & $x$ \\
\hline Convolvulaceae & Ipomoea triloba L. & & $x$ \\
\hline Convolvulaceae & Merremia aegyptia (L.) Urb. & & $x$ \\
\hline Cyperaceae & Cyperus rotundus $L$. & $x$ & $x$ \\
\hline Euphorbiaceae & Euphorbia heterophylla L. & $x$ & $x$ \\
\hline Euphorbiaceae & Euphorbia hirta L. & $x$ & $x$ \\
\hline Euphorbiaceae & Euphorbia hyssopifolia L. & $x$ & $x$ \\
\hline Euphorbiaceae & Phyllanthus amarus Schumach. \& Thonn. & $x$ & \\
\hline Fabaceae & Desmanthus virgatus (L.) Willd. & $\mathrm{x}$ & $x$ \\
\hline Fabaceae & Mimosa pudica $L$. & & $x$ \\
\hline Fabaceae & Senna occidentalis (L.) Roxb. & & $x$ \\
\hline Lamiaceae & Leucas lavandulifolia Sm. & $\mathrm{x}$ & \\
\hline Malvaceae & Malvastrum coromandelianum (L.) Garcke & $x$ & \\
\hline Papaveraceae & Argemone mexicana $L$. & $\mathrm{x}$ & \\
\hline Plantaginaceae & Plantago lanceolata $L$. & $x$ & \\
\hline Poaceae & Brachiaria decumbens Stapf & & $x$ \\
\hline Poaceae & Dactyloctenium aegyptium (L.) P.Beauv. & $\mathrm{x}$ & \\
\hline Poaceae & Eleusine indica (L.) Gaertn. & $\mathrm{x}$ & \\
\hline Poaceae & Panicum maximum Jacq. & $x$ & \\
\hline Portulacaceae & Portulaca oleracea $L$. & $\mathrm{x}$ & $x$ \\
\hline Sapindaceae & Cardiospermum microcarpum Kunth & $\mathrm{x}$ & $\mathrm{x}$ \\
\hline Solanaceae & Nicandra physalodes (L.) Gaertn. & $x$ & \\
\hline Solanaceae & Solanum americanum Mill. & & $x$ \\
\hline
\end{tabular}


Table A3. Species composition in each trial and sowing density (SD) of pure crops. The trial IDs are detailed in Table 1 in the main text.

\begin{tabular}{|c|c|c|c|c|c|c|c|c|c|c|c|}
\hline \multirow[b]{2}{*}{ Species } & \multirow[b]{2}{*}{$\begin{array}{l}\text { SD } \\
\left(\mathrm{kg} \mathrm{ha}^{-1}\right)\end{array}$} & \multicolumn{6}{|c|}{ Cover crop trials ID } & \multicolumn{4}{|c|}{$\begin{array}{l}\text { Weed control trials } \\
\text { ID }\end{array}$} \\
\hline & & 1 & 2 & 3 & 4 & 5 & 6 & 7 & 8 & 9 & 10 \\
\hline $\begin{array}{l}\text { Cichorium endivia L. } \\
\text { Guizotia abyssinica (L.f.) Cass. }\end{array}$ & \begin{tabular}{|l|}
7 \\
10 \\
\end{tabular} & $\mathrm{x}$ & $\begin{array}{l}X \\
X \\
\end{array}$ & $\mathrm{x}$ & $\mathrm{x}$ & & $\mathrm{x}$ & & & $\mathrm{x}$ & \\
\hline $\begin{array}{l}\text { Brassica carinata A.Braun } \\
\text { Raphanus sativus L. } \\
\text { Sinapis alba L. }\end{array}$ & \begin{tabular}{|l|}
6 \\
10 \\
10 \\
\end{tabular} & $\mathrm{x}$ & $x$ & $\begin{array}{l}x \\
X \\
\end{array}$ & $\begin{array}{l}\mathrm{x} \\
\mathrm{x}\end{array}$ & $x$ & $\mathrm{x}$ & & & & $x$ \\
\hline Arachis hypogaea $\mathrm{L}$. & 150 & $\mathrm{x}$ & $\mathrm{x}$ & $\mathrm{x}$ & & & & & & & \\
\hline Cajanus cajan (L.) Huth & 10 & $\mathrm{x}$ & $\mathrm{x}$ & $\mathrm{x}$ & $\mathrm{x}$ & & & & & & \\
\hline Canavalia ensiformis (L.) DC. & 40 & $\mathrm{x}$ & $\mathrm{x}$ & $\mathrm{x}$ & $\mathrm{x}$ & $\mathrm{x}$ & $\mathrm{x}$ & $\mathrm{x}$ & $\mathrm{x}$ & & $\mathrm{x}$ \\
\hline Canavalia gladiata (Jacq.) DC. & 40 & $\mathrm{x}$ & $\mathrm{x}$ & & & $\mathrm{x}$ & & & & & \\
\hline Centrosema pascuorum Mart. ex Benth. & 15 & $\mathrm{x}$ & & & & $\mathrm{x}$ & & & & & \\
\hline Crotalaria juncea L. & 40 & $\mathrm{x}$ & $\mathrm{x}$ & $\mathrm{x}$ & $\mathrm{x}$ & $\mathrm{x}$ & $\mathrm{x}$ & $\mathrm{x}$ & $\mathrm{x}$ & $\mathrm{x}$ & $\mathrm{x}$ \\
\hline Crotalaria retusa $\mathrm{L}$. & 25 & $\mathrm{x}$ & & & & & & & & & \\
\hline Crotalaria spectabilis Roth & 20 & $\mathrm{x}$ & & $\mathrm{x}$ & $\mathrm{x}$ & $\mathrm{x}$ & $\mathrm{x}$ & & & & \\
\hline Crotalaria trichotoma Bojer & 25 & $\mathrm{x}$ & $\mathrm{x}$ & $\mathrm{x}$ & & $\mathrm{x}$ & $\mathrm{x}$ & & & & \\
\hline Grona heterocarpa (L.) H.Ohashi \& K.Ohashi & 20 & $\mathrm{x}$ & & & & & & & & & \\
\hline Lablab purpureus (L.) Sweet & 50 & $\mathrm{x}$ & $\mathrm{x}$ & $\mathrm{x}$ & $\mathrm{x}$ & $\mathrm{x}$ & & & & & \\
\hline Lathyrus sativus L. & 50 & $\mathrm{x}$ & & & & $\mathrm{x}$ & $\mathrm{x}$ & & & & \\
\hline Lens nigricans (M.Bieb.) Webb \& Berthel. & 80 & $\mathrm{x}$ & & & & & & & & & \\
\hline Lotus corniculatus L. & 8 & & $\mathrm{x}$ & & & & & & & & \\
\hline Lupinus albus L. & 150 & & $\mathrm{x}$ & & & & & & & & \\
\hline Macrotyloma axillare (E.Mey.) Verdc. & 4 & $\mathrm{x}$ & & & & & $\mathrm{x}$ & & & & \\
\hline Medicago sativa $\mathrm{L}$. & 25 & $\mathrm{x}$ & $\mathrm{x}$ & $\mathrm{x}$ & & $\mathrm{x}$ & $\mathrm{x}$ & & & & \\
\hline Mucuna pruriens (L.) DC. & 35 & $\mathrm{x}$ & $\mathrm{x}$ & $\mathrm{x}$ & & $\mathrm{x}$ & $\mathrm{x}$ & & & & \\
\hline Neonotonia wightii (Wight \& Arn.) J.A.Lackey & 25 & $\mathrm{x}$ & $\mathrm{x}$ & & & & & & & & \\
\hline Neustanthus phaseoloides (Roxb.) Benth. & 20 & $\mathrm{x}$ & $\mathrm{x}$ & & & & & & & & \\
\hline Phaseolus lunatus $\mathrm{L}$. & 80 & $\mathrm{x}$ & $\mathrm{x}$ & $\mathrm{x}$ & & $\mathrm{x}$ & $\mathrm{x}$ & & & & \\
\hline Pisum sativum L. & 100 & & & & $\mathrm{x}$ & & & & & & \\
\hline Stylosanthes guianensis (Aubl.) Sw. & 8 & $\mathrm{x}$ & $\mathrm{x}$ & & & $\mathrm{x}$ & $\mathrm{x}$ & $\mathrm{x}$ & $\mathrm{x}$ & & \\
\hline Trifolium hybridum L. & 15 & & & $\mathrm{x}$ & & & & & & & \\
\hline Trifolium incarnatum L. & 15 & & & $\mathrm{x}$ & & & & & & & \\
\hline Trifolium pratense $\mathrm{L}$. & 8 & & & $\mathrm{x}$ & & & & & & & \\
\hline Trifolium repens $\mathrm{L}$. & 10 & & & $\mathrm{x}$ & & & & & & & \\
\hline Trigonella foenum-graecum L. & 35 & $\mathrm{x}$ & $\mathrm{x}$ & & & & & & & & \\
\hline Vicia villosa Roth & 20 & & $\mathrm{x}$ & $\mathrm{x}$ & $\mathrm{x}$ & & & & & $\mathrm{x}$ & \\
\hline Vigna radiata (L.) R.Wilczek & 10 & $\mathrm{x}$ & $\mathrm{x}$ & $\mathrm{x}$ & & $\mathrm{x}$ & $\mathrm{x}$ & & & & \\
\hline Vigna subterranea (L.) Verdc. & 90 & $\mathrm{x}$ & $\mathrm{x}$ & $\mathrm{x}$ & & & $\mathrm{x}$ & & & & \\
\hline Vigna unguiculata (L.) Walp. & 15 & $\mathrm{x}$ & $\mathrm{x}$ & $\mathrm{x}$ & $\mathrm{x}$ & $\mathrm{x}$ & $\mathrm{x}$ & & & $\mathrm{x}$ & \\
\hline Avena sativa $\mathrm{L}$. & 90 & & $x$ & $x$ & $x$ & $x$ & $x$ & $\mathrm{x}$ & $\mathrm{x}$ & $x$ & \\
\hline Avena strigosa Schreb. & 40 & & $\mathrm{x}$ & $\mathrm{x}$ & $\mathrm{x}$ & & & & & & \\
\hline Eleusine coracana (L.) Gaertn. & 3 & $\mathrm{x}$ & & & & & & & $\mathrm{x}$ & & \\
\hline Pennisetum glaucum (L.) R.Br. & 20 & $\mathrm{x}$ & $\mathrm{x}$ & $\mathrm{x}$ & $\mathrm{x}$ & $\mathrm{x}$ & $\mathrm{x}$ & $\mathrm{x}$ & $x$ & $\mathrm{x}$ & $\mathrm{x}$ \\
\hline Phalaris canariensis L. & 4 & $\mathrm{x}$ & & & & & & & & & \\
\hline Sorghum bicolor (L.) Moench & 11 & $\mathrm{x}$ & $\mathrm{x}$ & & & $x$ & $\mathrm{x}$ & $\mathrm{x}$ & $\mathrm{x}$ & & \\
\hline Urochloa eminii (Mez) Davidse & 8 & $\mathrm{x}$ & & & & & & & & & \\
\hline Zea mays L. & 15 & & & $\mathrm{x}$ & & & & & & & \\
\hline Fagopyrum esculentum Moench & 40 & & $\mathrm{x}$ & $\mathrm{x}$ & $\mathrm{x}$ & & & & & & \\
\hline
\end{tabular}

Crotalaria zanzibarica Benth. synonym of Crotalaria trichotoma Bojer

Desmodium heterocarpon (L.) DC. synonym of Grona heterocarpa (L.) H.Ohashi \& K.Ohashi Pueraria phaseoloides (Roxb.) Benth. synonym of Neustanthus phaseoloides (Roxb.) Benth. Brachiaria decumbens Stapf synonym of Urochloa eminii (Mez) Davidse Cenchrus americanus (L.) Morrone synonym of Pennisetum glaucum (L.) R.Br. 
Table A4. List of cover crop species used in the different trials. The family, life cycle ( $A=a n n u a l$, $\mathrm{P}=$ perennial), area of origin ( $\mathrm{Tr}=$ tropical, $\mathrm{Tm}=$ temperate) and the growth habit $(\mathrm{E}=$ erect, $\mathrm{C}=$ creeping, $\mathrm{V}=$ vines) of each species are described.

\begin{tabular}{|c|c|c|c|c|}
\hline Family & Species & Cycle & Zone & Growth habit \\
\hline Asteraceae & $\begin{array}{l}\text { Cichorium endivia L. } \\
\text { Guizotia abyssinica (L.f.) Cass. }\end{array}$ & A & $\begin{array}{l}\mathrm{Tm} \\
\mathrm{Tm}\end{array}$ & $\begin{array}{l}E \\
E\end{array}$ \\
\hline Brassicaceae & $\begin{array}{l}\text { Brassica carinata A.Braun } \\
\text { Raphanus sativus L. } \\
\text { Sinapis alba } \mathrm{L} \text {. }\end{array}$ & $\begin{array}{l}A \\
A \\
A\end{array}$ & $\begin{array}{l}\mathrm{Tm} \\
\mathrm{Tm} \\
\mathrm{Tm}\end{array}$ & $\begin{array}{l}E \\
E \\
E\end{array}$ \\
\hline Fabaceae & $\begin{array}{l}\text { Arachis hypogaea L. } \\
\text { Cajanus cajan (L.) Huth } \\
\text { Canavalia ensiformis (L.) DC. } \\
\text { Canavalia gladiata (Jacq.) DC. } \\
\text { Centrosema pascuorum Mart. ex Benth. } \\
\text { Crotalaria juncea L. } \\
\text { Crotalaria retusa L. } \\
\text { Crotalaria spectabilis Roth } \\
\text { Crotalaria trichotoma Bojer } \\
\text { Grona heterocarpa (L.) H.Ohashi \& K.Ohashi } \\
\text { Lablab purpureus (L.) Sweet } \\
\text { Lathyrus sativus L. } \\
\text { Lens nigricans (M.Bieb.) Webb \& Berthel. } \\
\text { Lotus corniculatus L. } \\
\text { Lupinus albus L. } \\
\text { Macrotyloma axillare (E.Mey.) Verdc. } \\
\text { Medicago sativa L. } \\
\text { Mucuna pruriens (L.) DC. } \\
\text { Neonotonia wightii (Wight \& Arn.) J.A.Lackey } \\
\text { Neustanthus phaseoloides (Roxb.) Benth. } \\
\text { Phaseolus lunatus L. } \\
\text { Pisum sativum L. } \\
\text { Stylosanthes guianensis (Aubl.) Sw. } \\
\text { Trifolium hybridum L. } \\
\text { Trifolium incarnatum L. } \\
\text { Trifolium pratense L. } \\
\text { Trifolium repens L. } \\
\text { Trigonella foenum-graecum L. } \\
\text { Vicia villosa Roth } \\
\text { Vigna radiata (L.) R.Wilczek } \\
\text { Vigna subterranea (L.) Verdc. } \\
\text { Vigna unguiculata (L.) Walp. }\end{array}$ & $\begin{array}{l}\text { A } \\
P \\
A \\
A \\
A \\
A \\
A \\
A \\
A \\
A \\
A \\
A \\
A \\
A \\
A \\
P \\
P \\
A \\
P \\
P \\
A \\
A \\
P \\
P \\
A \\
P \\
P \\
A \\
A \\
A \\
A \\
A\end{array}$ & $\begin{array}{l}\text { Tr } \\
\mathrm{Tr} \\
\mathrm{Tr} \\
\mathrm{Tr} \\
\mathrm{Tr} \\
\mathrm{Tr} \\
\mathrm{Tr} \\
\mathrm{Tr} \\
\mathrm{Tr} \\
\mathrm{Tr} \\
\mathrm{Tr} \\
\mathrm{Tm} \\
\mathrm{Tm} \\
\mathrm{Tm} \\
\mathrm{Tm} \\
\mathrm{Tr} \\
\mathrm{Tm} \\
\mathrm{Tr} \\
\mathrm{Tr} \\
\mathrm{Tr} \\
\mathrm{Tr} \\
\mathrm{Tm} \\
\mathrm{Tr} \\
\mathrm{Tm} \\
\mathrm{Tm} \\
\mathrm{Tm} \\
\mathrm{Tm} \\
\mathrm{Tm} \\
\mathrm{Tm} \\
\mathrm{Tr} \\
\mathrm{Tr} \\
\mathrm{Tr}\end{array}$ & 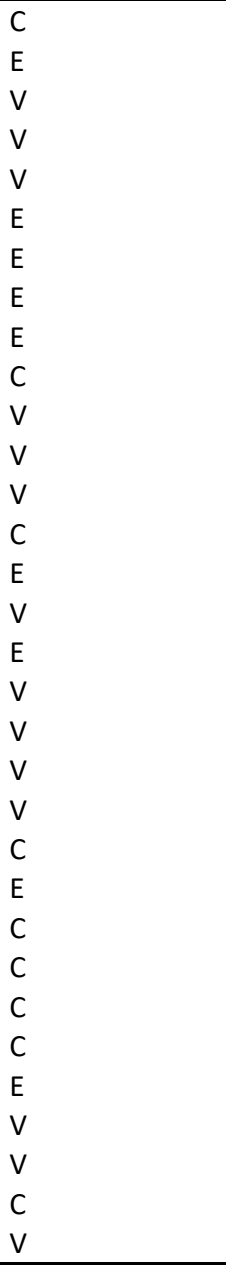 \\
\hline Poaceae & $\begin{array}{l}\text { Avena sativa } \mathrm{L} . \\
\text { Avena strigosa Schreb. } \\
\text { Eleusine coracana (L.) Gaertn. } \\
\text { Pennisetum glaucum (L.) R.Br. } \\
\text { Phalaris canariensis L. } \\
\text { Sorghum bicolor (L.) Moench } \\
\text { Urochloa eminii (Mez) Davidse } \\
\text { Zea mays L. }\end{array}$ & $\begin{array}{l}\text { A } \\
A \\
A \\
A \\
A \\
A \\
P \\
A\end{array}$ & $\begin{array}{l}\text { Tm } \\
\text { Tm } \\
\text { Tr } \\
\operatorname{Tr} \\
\operatorname{Tm} \\
\operatorname{Tr} \\
\operatorname{Tr} \\
\operatorname{Tr}\end{array}$ & $\begin{array}{l}E \\
E \\
E \\
E \\
E \\
E \\
E \\
E\end{array}$ \\
\hline Polygonaceae & Fagopyrum esculentum Moench & A & $\mathrm{Tm}$ & $\mathrm{E}$ \\
\hline
\end{tabular}


Table A5. Mixture of two species tested in the weed control trials. The trial IDs are detailed in Table 1 in the main text. In case of a mixture, the sowing density was half the density used for pure crops.

\begin{tabular}{|lll|}
\hline \multicolumn{2}{|c|}{ Mixture of species } & Weed control trial ID \\
\hline Avena sativa & Canavalia ensiformis & 7 \\
Avena sativa & Crotalaria juncea & 7,9 \\
Avena sativa & Stylosanthes guianensis & 7 \\
Avena sativa & Vicia villosa & 9 \\
Avena sativa & Vigna unguiculata & 9 \\
Canavalia ensiformis & Pennisetum glaucum & 10,7 \\
Canavalia ensiformis & Raphanus sativus & 10 \\
Pennisetum glaucum & Crotalaria juncea & $7,9,10$ \\
Pennisetum glaucum & Stylosanthes guianensis & 7 \\
Pennisetum glaucum & Vigna unguiculata & 9 \\
Guizotia abyssinica & Crotalaria juncea & 9 \\
Sorghum bicolor & Canavalia ensiformis & 7 \\
Sorghum bicolor & Crotalaria juncea & 7 \\
Sorghum bicolor & Stylosanthes guianensis & 7 \\
\hline
\end{tabular}

Table A6. Notation methods used to assess ground cover by plants (weeds or cover crops). The choice of notation was made by following a multi-step decision tree. At each step, the decision has to be taken if we estimate it to be above or below a value (e.g. 50\% cover in the first step, at least one individual per $\mathrm{m}^{2}$ in the second step, etc).

\begin{tabular}{|c|c|l|}
\hline Notation & Equivalence in percentage & \multicolumn{1}{c|}{ coverage } \\
\hline 1 & 1 & Species present but rare \\
\hline 2 & 7 & Less than one individual per $\mathrm{m}^{2}$ \\
\hline 3 & 15 & At least one individual per $\mathrm{m}^{2}$ \\
\hline 4 & 30 & $30 \%$ of coverage \\
\hline 5 & 50 & $50 \%$ of coverage \\
\hline 6 & 70 & $70 \%$ of coverage \\
\hline 7 & 85 & High coverage \\
\hline 8 & 93 & Very little apparent soil \\
\hline 9 & 100 & Full coverage \\
\hline
\end{tabular}

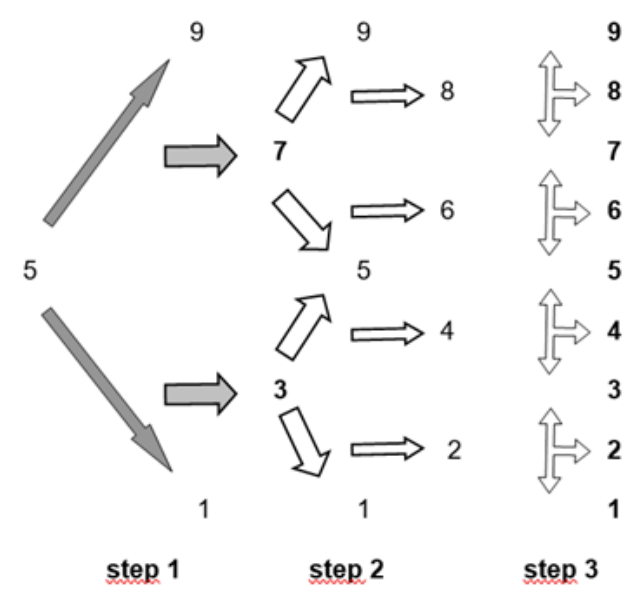




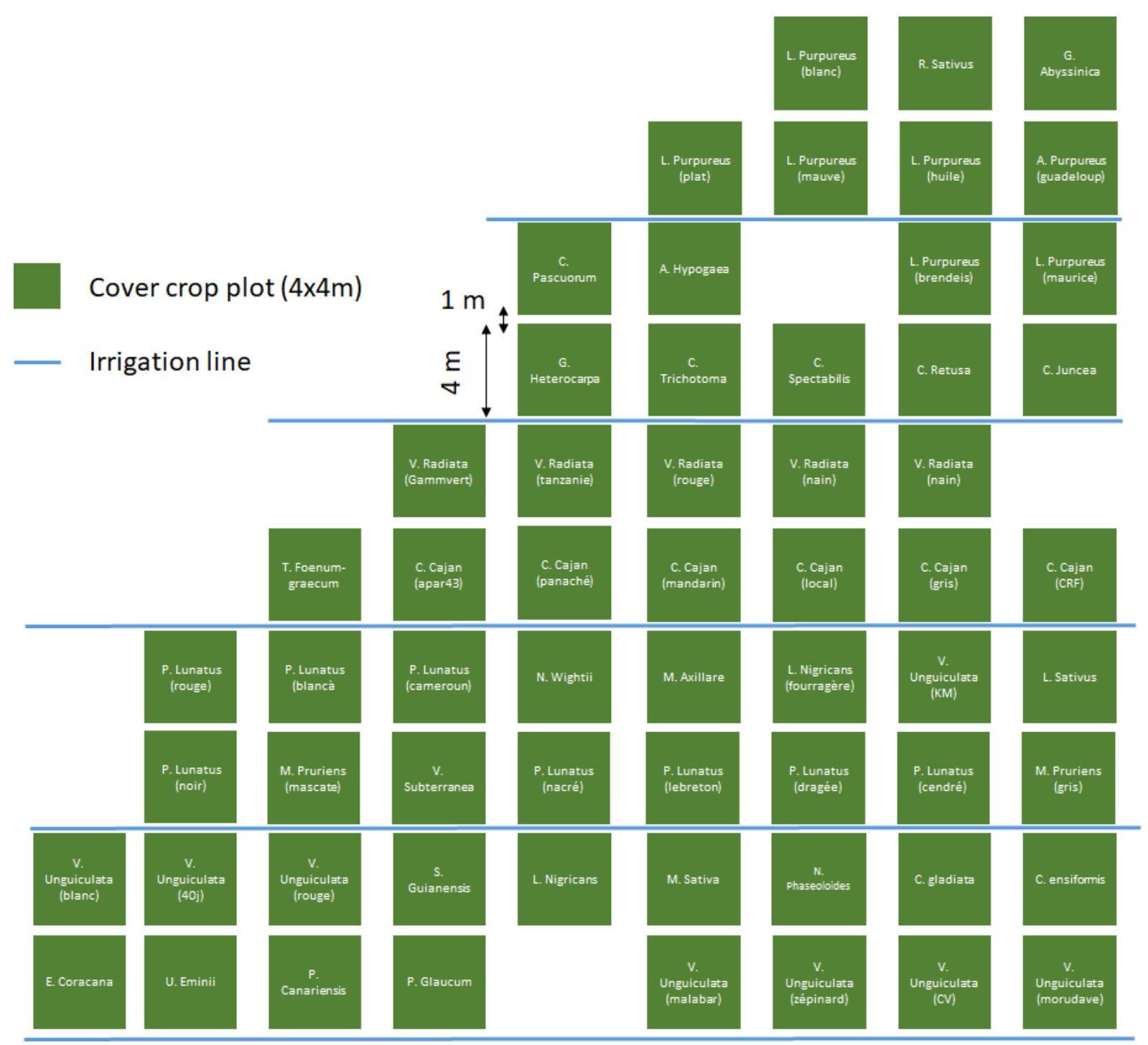

Fig A1. Experimental design of the cover crop trial ID 1 in La Mare 2016. 


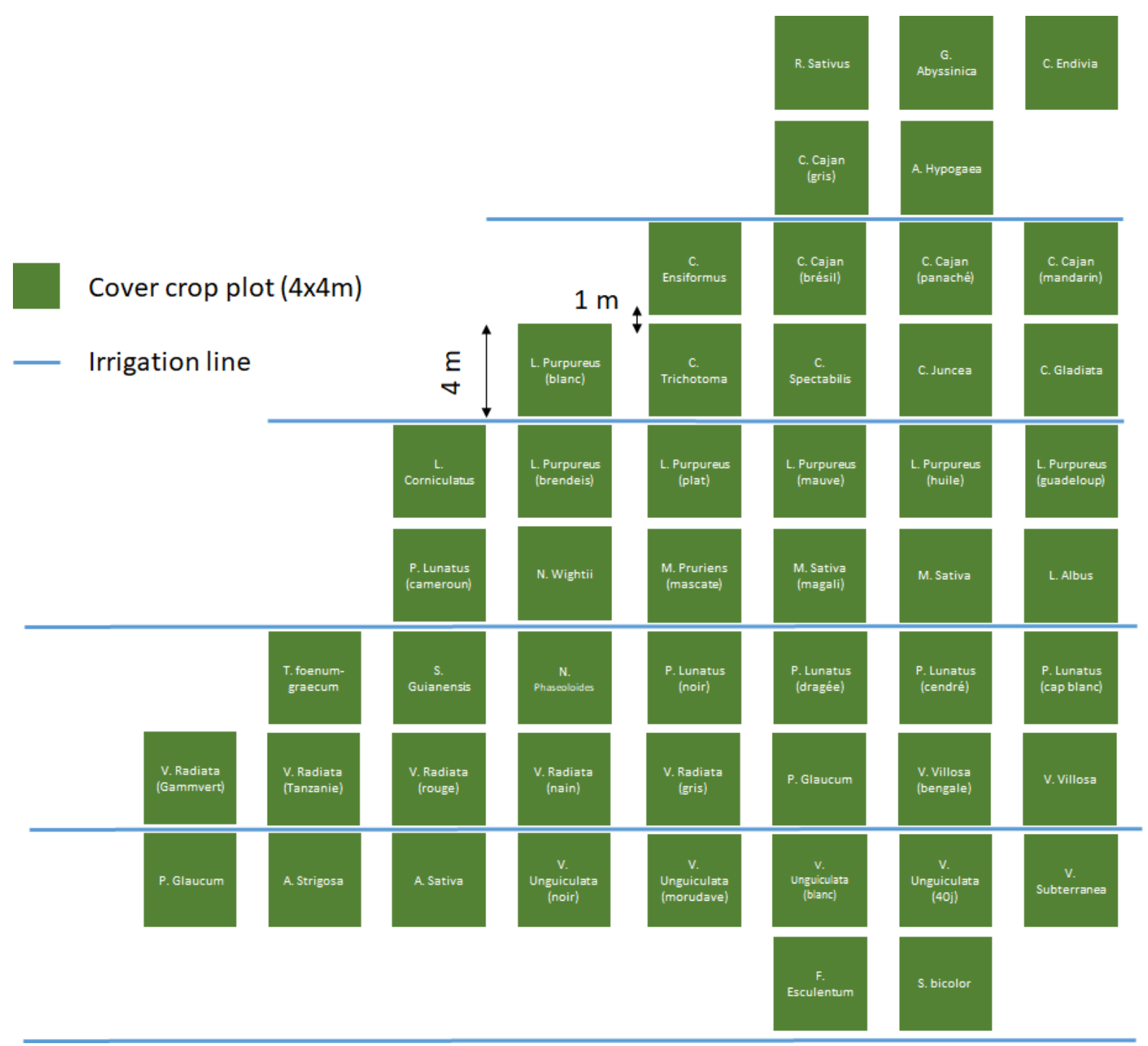

Fig A2. Experimental design of the cover crop trial ID 2 in La Mare 2017 


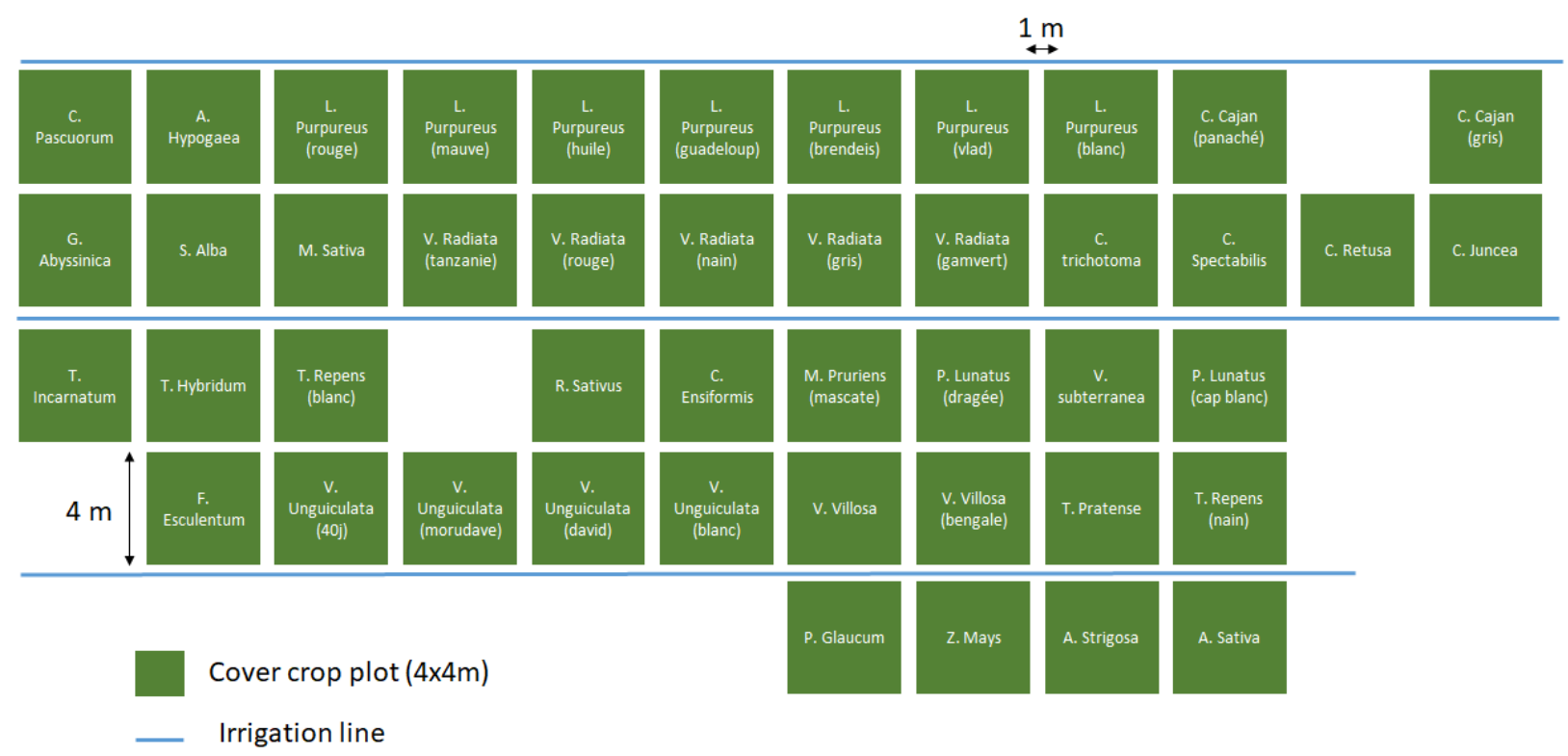

Fig A3. Experimental design of the cover crop trial ID 3 in La Mare 2018

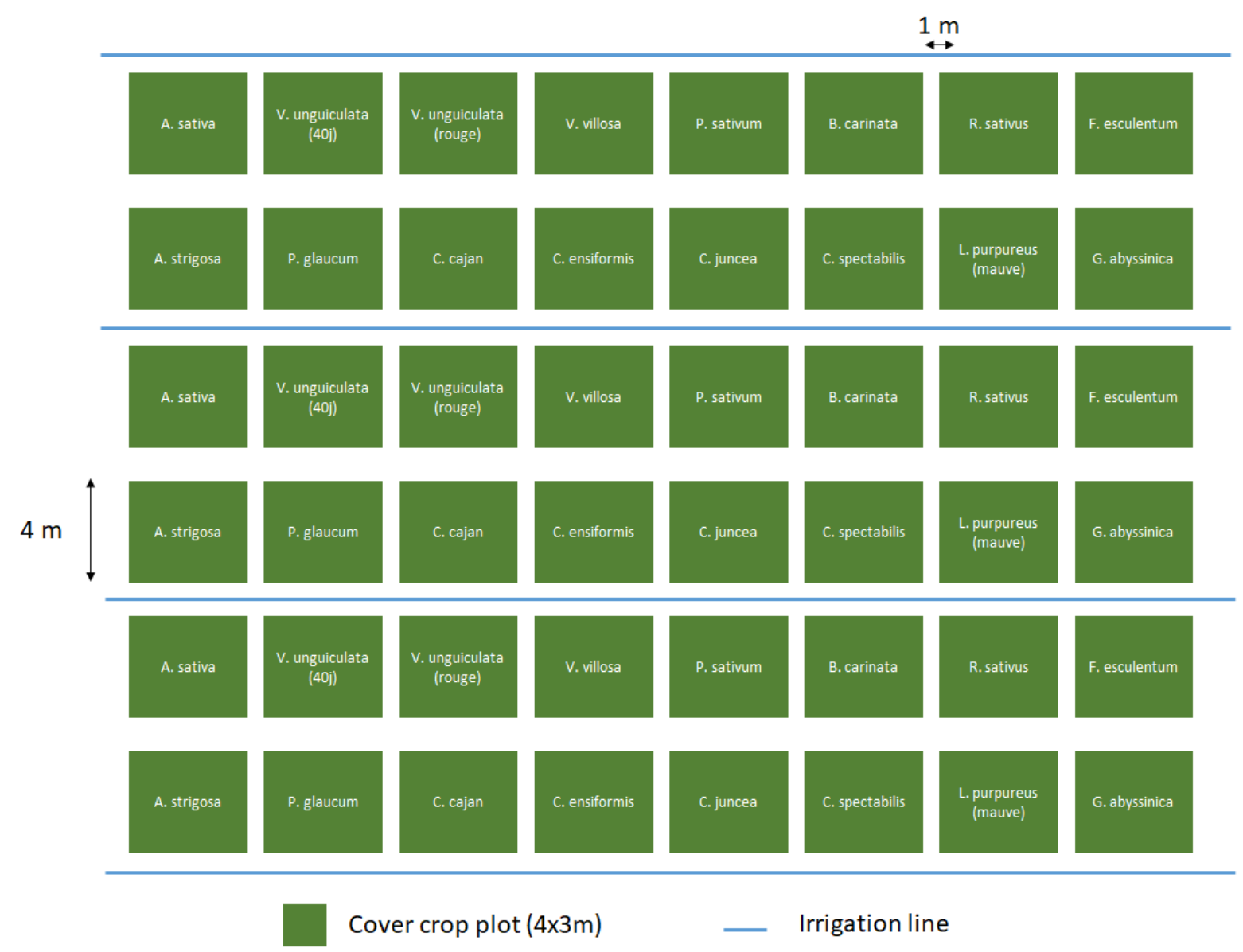

Fig A4. Experimental design of the cover crop trial ID 4 in La Mare 2018 


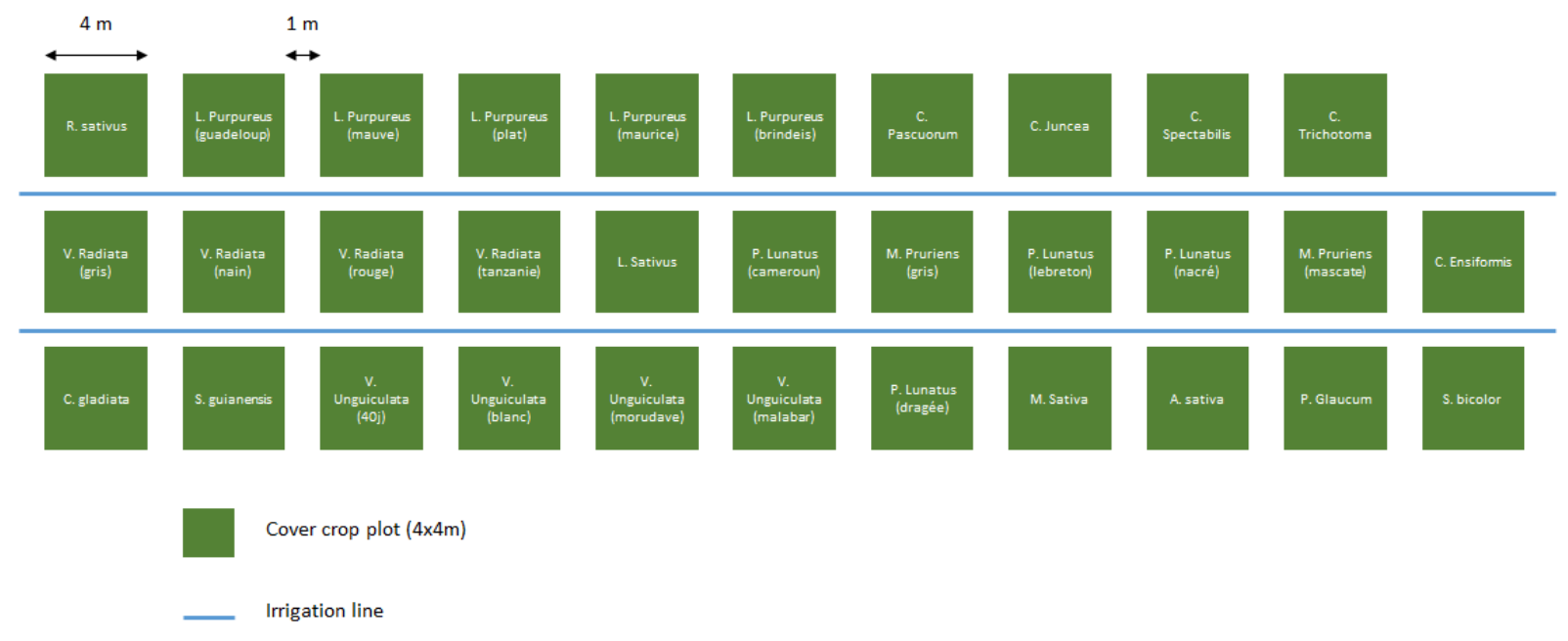

Fig A5. Experimental design of the cover crop trial ID 5 in Bassin Plat 2016

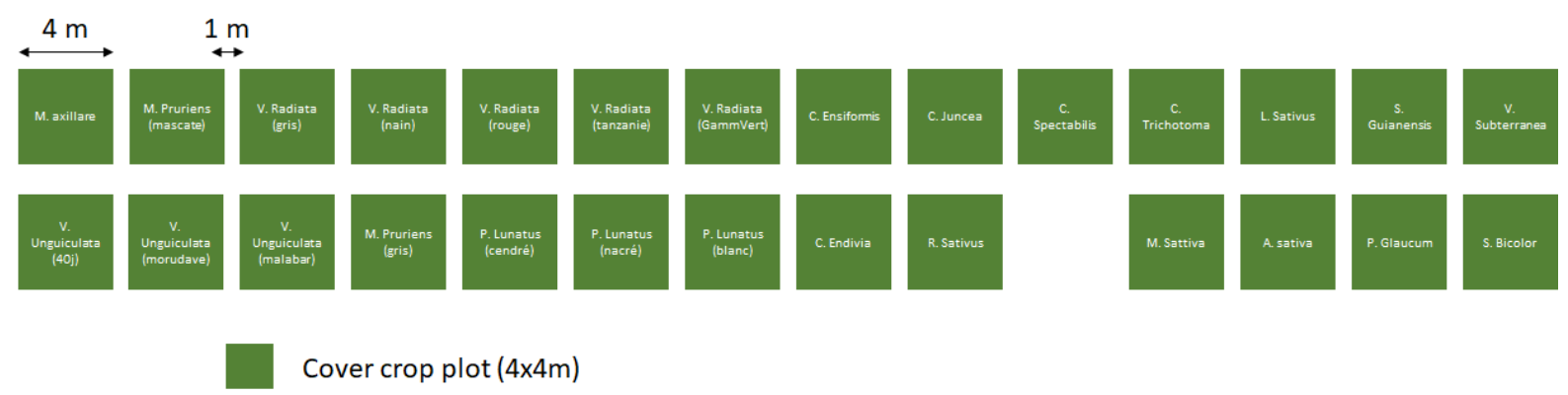

Fig A6. Experimental design of the cover crop trial ID 6 in Colimaçon 2016 


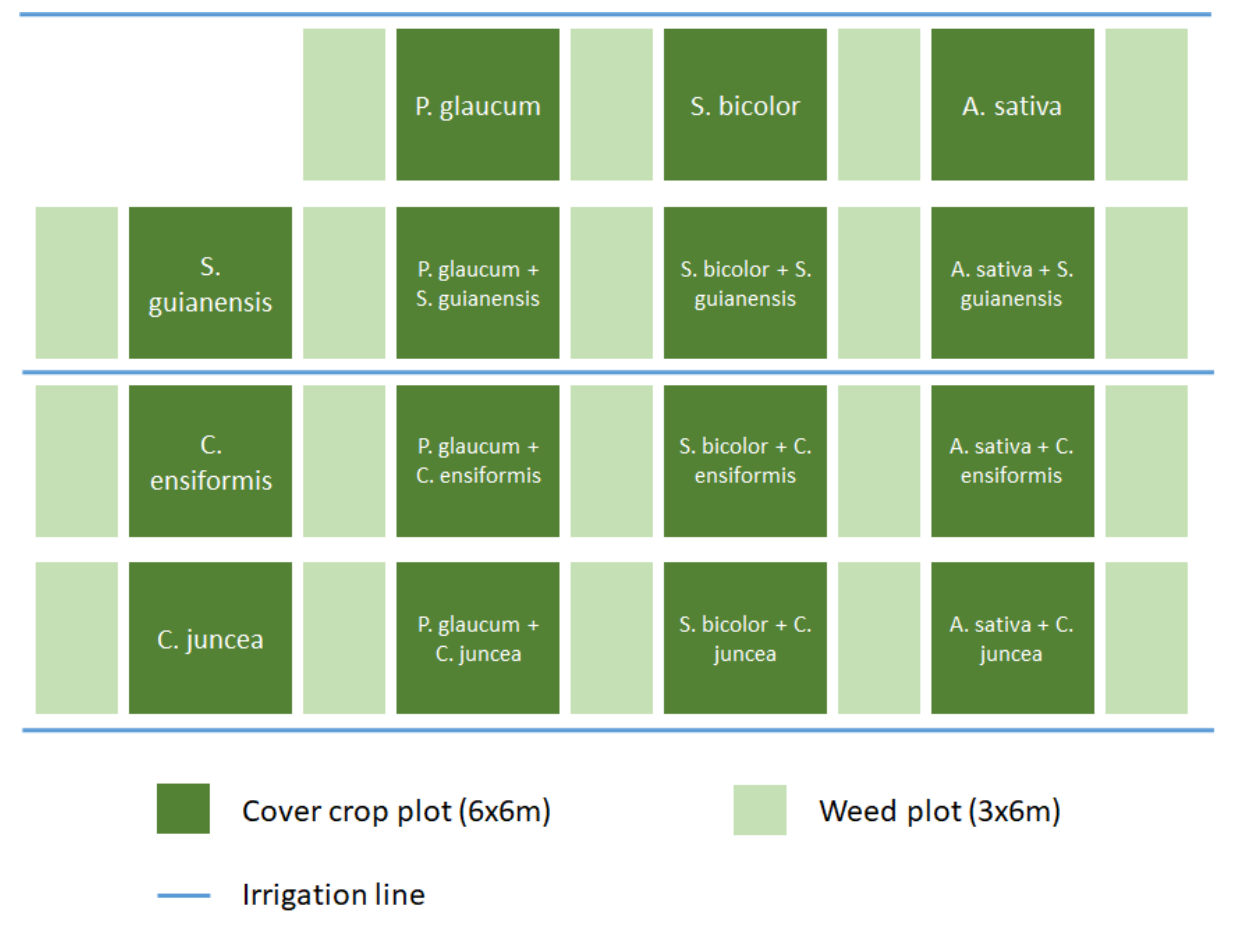

Fig A7. Experimental design of the weed control trial ID 7 in La Mare 2016

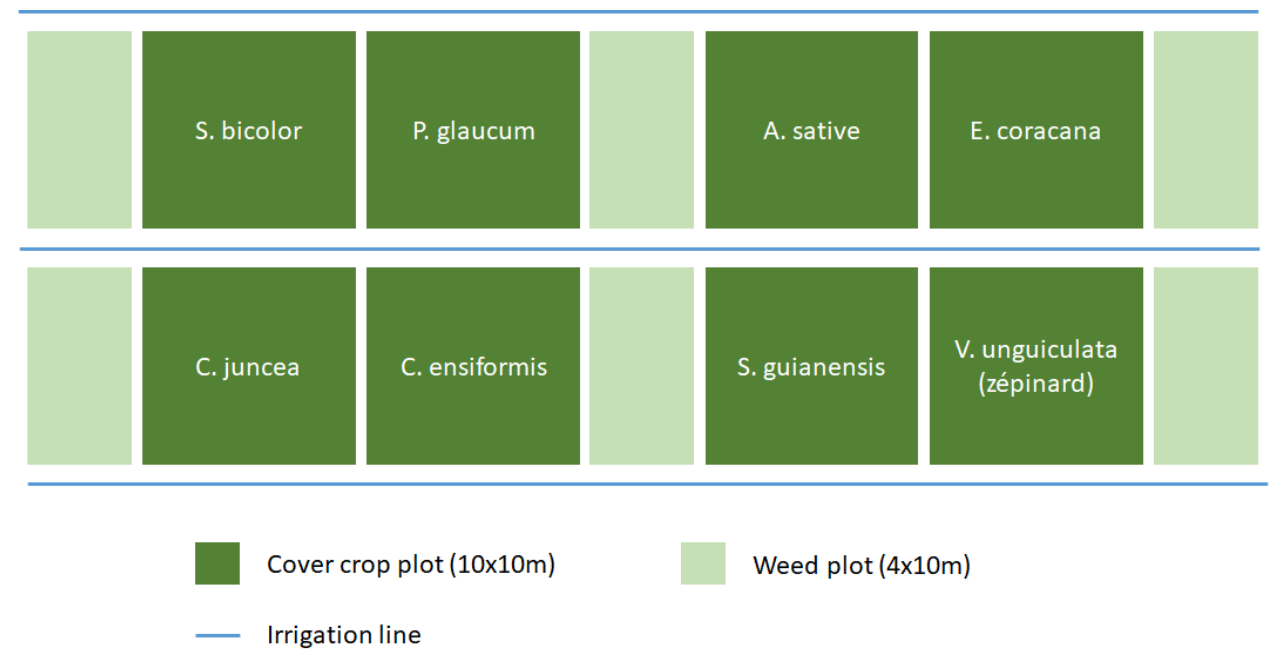

Fig A8. Experimental design of the weed control trial ID 8 in La Mare 2016 


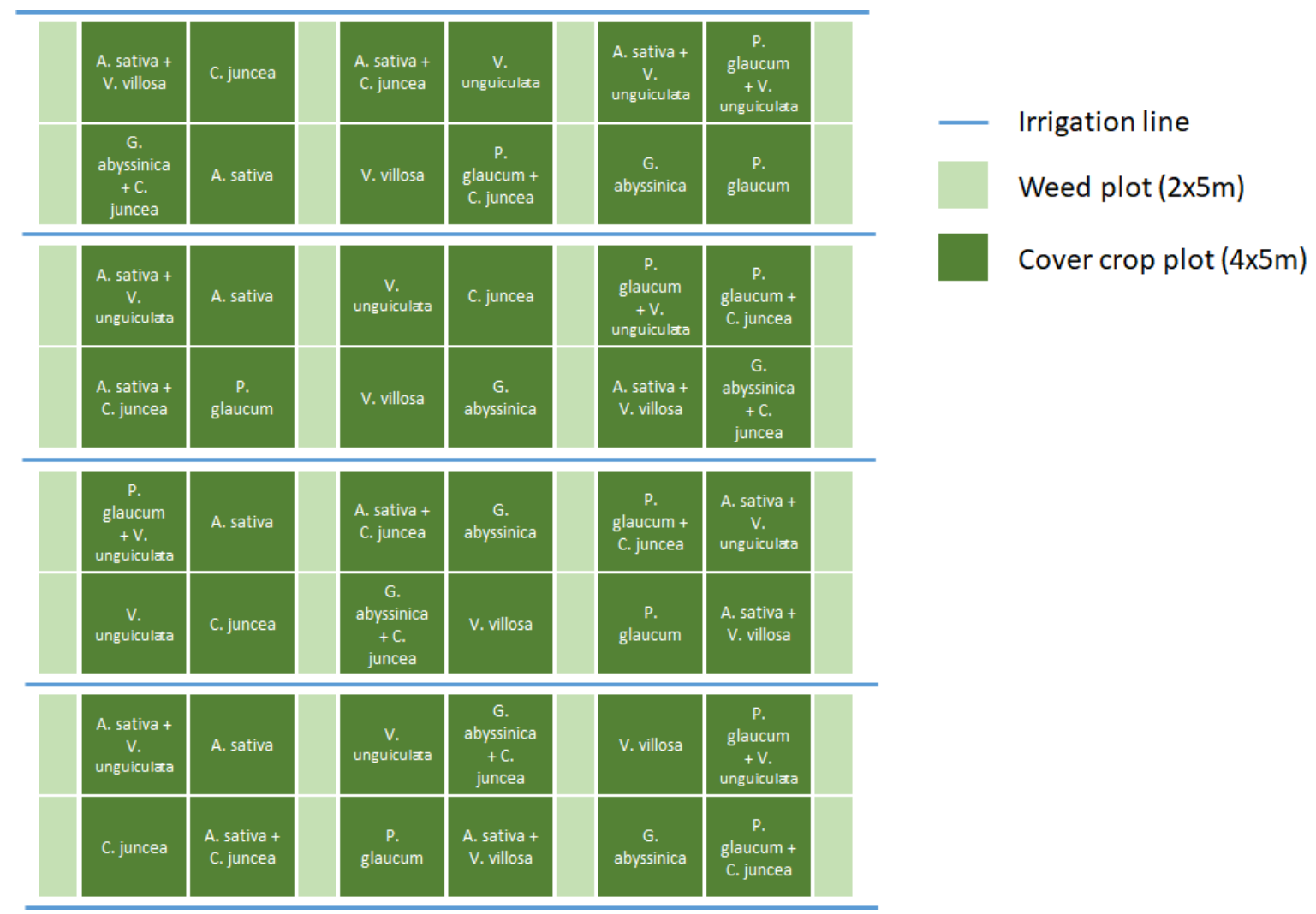

Fig A9. Experimental design of the weed control trial ID 9 in La Mare 2017

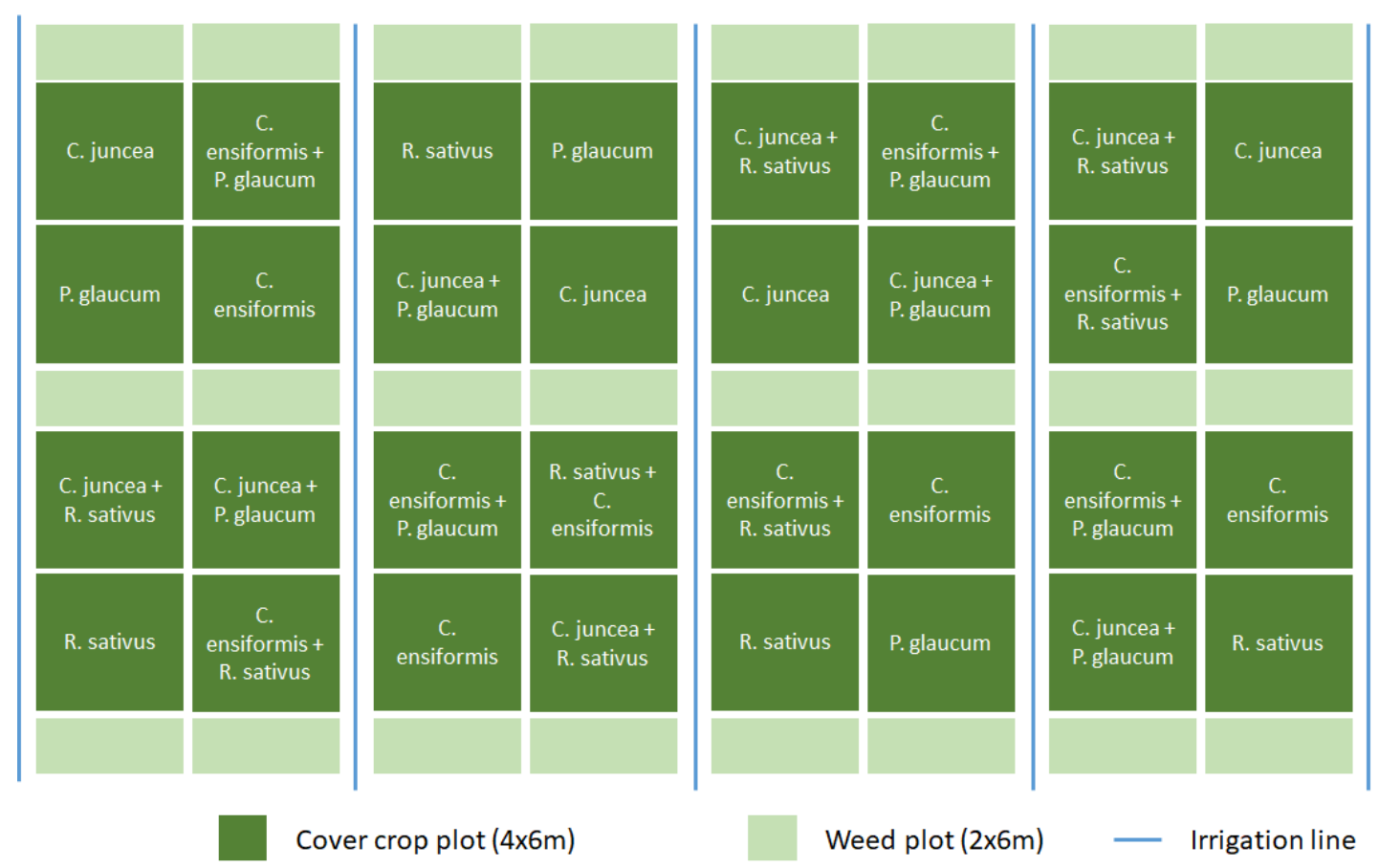

Fig A10. Experimental design of the weed control trial ID 10 in Bassin Plat 2017. 


\section{Supplementary Information B: Complementary Results}

Table B1. Chi-square test on available $\mathrm{COV}_{\text {MEAN }}$ data contingency table between site location, average temperature ( $\mathrm{T}_{\text {MEAN }}$ ), fertilization regime, cover crop genus, family, area of origin, life cycle and growth habit in the cover crop trials. The chis-square value is indicated with degree of freedom (df). P. values are abbreviated by ns, ${ }^{*}, * *, * * *$ when $>0.05$, lower than $0.05,0.01$ and 0.001 , respectively.

\begin{tabular}{|c|c|c|c|c|c|}
\hline & Genus & Family & Area of origin & Life cycle & Growth habit \\
\hline Location & $\mathrm{X}_{\mathrm{df}=70}=48.0 \mathrm{~ns}$ & $\mathrm{X}_{\mathrm{df}=8}^{2}=3.5 \mathrm{~ns}$ & $\mathrm{X}_{\mathrm{df}=2}^{2}=5.1 \mathrm{~ns}$ & $\mathrm{X}_{\mathrm{df}=2}^{2}=2.2 \mathrm{~ns}$ & $\mathrm{X}_{\mathrm{df}=8}^{2}=5.7 \mathrm{~ns}$ \\
\hline$T_{\text {MEAN }}$ & $\mathrm{X}_{\mathrm{df}=140}=90.8 \mathrm{~ns}$ & $X_{d f=16}^{2}=16 n s$ & $X_{d f=4}^{2}=11.4^{*}$ & $\mathrm{X}_{\mathrm{df}=4}^{2}=6.5 \mathrm{~ns}$ & $\mathrm{X}_{\mathrm{df}=8}=10.9 \mathrm{~ns}$ \\
\hline Fertilization & $X_{d f=36}^{2}=59.9^{* *}$ & $\mathrm{X}_{\mathrm{df}=4}^{2}=11.6^{*}$ & $\mathrm{X}_{\mathrm{df}=1}^{2}=18.7^{* * *}$ & $\mathrm{X}_{\mathrm{df}=1}^{2}<0.1 \mathrm{~ns}$ & $\mathrm{X}_{\mathrm{df}=2}^{2}=9.5^{* *}$ \\
\hline Genus & & $\mathrm{X}_{\mathrm{df}=144}^{2}=1052 * * *$ & $\mathrm{X}_{\mathrm{df}=36}^{2}=263^{* * *}$ & $\mathrm{X}_{\mathrm{df}=36}^{2}=250 * * *$ & $\mathrm{X}_{\mathrm{df}=72}^{2}=470 * * *$ \\
\hline Family & & & $\mathrm{X}_{\mathrm{df}=4}=90.6 * * *$ & $\mathrm{X}_{\mathrm{df}=4}^{2}=8.4 \mathrm{~ns}$ & $\mathrm{X}_{\mathrm{df}=8}^{2}=108 * * *$ \\
\hline Area of origin & & & & $\mathrm{X}_{\mathrm{df}=1}^{2}<0.1 \mathrm{~ns}$ & $\mathrm{X}_{\mathrm{df}=2}^{2}=46.7 * * *$ \\
\hline Life cycle & & & & & $\mathrm{X}_{\mathrm{df}=2}^{2}=22.4^{* * *}$ \\
\hline
\end{tabular}

Table B2. Proportion of data available in each area of origin depending on average air temperature $\left(\mathrm{T}_{\mathrm{MEAN}}\right)$ in the cover crop trials.

\begin{tabular}{|l|lllll|}
\cline { 2 - 6 } \multicolumn{1}{l|}{} & $\mathrm{T}_{\text {MEAN }}$ & & & & \\
\hline $\begin{array}{l}\text { Area of } \\
\text { origin }\end{array}$ & $20^{\circ} \mathrm{C}$ & $22^{\circ} \mathrm{C}$ & $23^{\circ} \mathrm{C}$ & $24^{\circ} \mathrm{C}$ & $26^{\circ} \mathrm{C}$ \\
\hline Temperate & $7 \%$ & $12 \%$ & $51 \%$ & $18 \%$ & $12 \%$ \\
\hline Tropical & $11 \%$ & $4 \%$ & $62 \%$ & $19 \%$ & $4 \%$ \\
\hline
\end{tabular}

Table B3. Proportion of data available in each area of origin and growth habit depending on the fertilization regime in the cover crop trials.

\begin{tabular}{|l|l|l|l|l|l|l|l|}
\cline { 2 - 8 } \multicolumn{1}{c|}{} & \multicolumn{2}{l|}{ Area of origin } & \multicolumn{2}{l|}{ Growth habit } \\
\hline $\begin{array}{l}\text { Fertilization } \\
\text { regime }\end{array}$ & $\begin{array}{l}\text { Temperate } \\
\text { species }\end{array}$ & $\begin{array}{l}\text { Tropical } \\
\text { species }\end{array}$ & Asteraceae & Brassicaceae & Fabaceae & Poaceae & Polygonaceae \\
\hline $\begin{array}{l}\text { Fertilized } \\
\text { Not fertilized }\end{array}$ & $25 \%$ & $56 \%$ & $25 \%$ & $25 \%$ & $53 \%$ & $0.4 \%$ & $0 \%$ \\
\hline
\end{tabular}

Table B4. Proportion of data available in each crop family depending on the growth habit in the cover crop trials.

\begin{tabular}{|c|c|c|c|c|c|}
\hline & \multicolumn{3}{|c|}{ Growth habit } & \multicolumn{2}{|c|}{ Area of origin } \\
\hline & Erect & Vines & Creeping & Temperate & Tropical \\
\hline Asteraceae & $8 \%$ & & & $12 \%$ & \\
\hline Brassicaceae & $12 \%$ & & & $18 \%$ & \\
\hline Fabaceae & $46 \%$ & $100 \%$ & $100 \%$ & $44 \%$ & $91 \%$ \\
\hline Poaceae & $29 \%$ & & & $19 \%$ & $9 \%$ \\
\hline Polygonaceae & $5 \%$ & & & $7 \%$ & \\
\hline
\end{tabular}




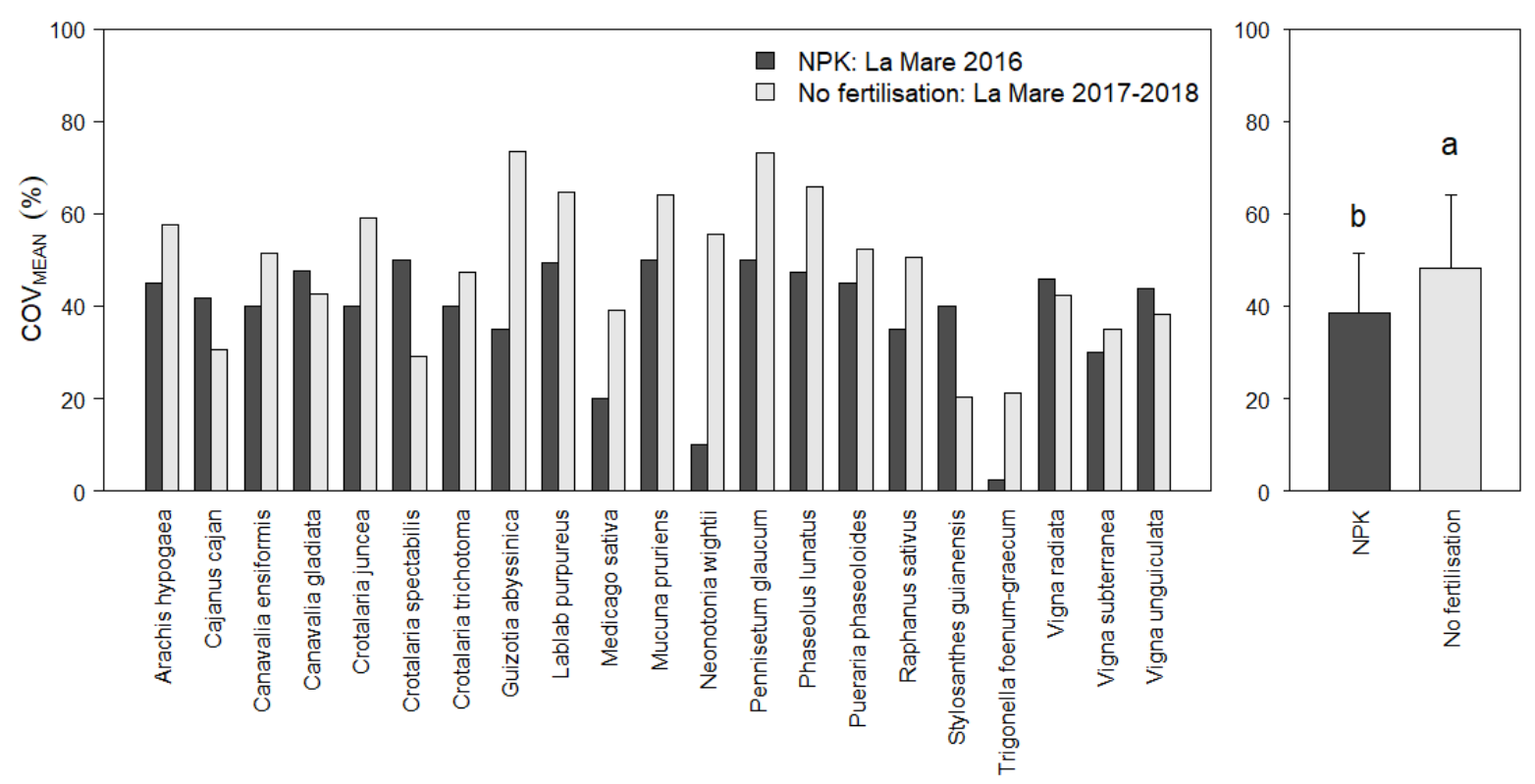

Fig B1. Comparison of mean ground cover $\left(\mathrm{COV}_{\mathrm{MEAN}}\right)$ for different cover crops in the fertilized cover crop trial in La Mare 2016 and the cover crop trials with no fertilization in La Mare 2017 and 2018 (left). The average COV MEAN across species depending on fertilization regime in $\mathrm{La}$ Mare is presented on the right. The difference between fertilization regime was tested using a Dunn test and indicated by letters a and $b$. 
Table B5. Variance analysis on crop traits in the cover crop trials using a mixed linear model with the crop life cycle and the combined crop family $\mathrm{x}$ area of origin as fixed effects, and the trial identification as random effect. To ensure the normality of residues, all crop traits were transformed using the Box-Cox power transformation (MASS package, boxcox function).

\begin{tabular}{|c|c|c|c|c|c|c|}
\hline & Life cycle & & & Family $x$ ar & ea of origin & \\
\hline Crop trait & $\mathrm{F}$ & $\mathrm{df}$ & $\mathrm{p}$ & $\mathrm{F}$ & $\mathrm{df}$ & $\mathrm{P}$ \\
\hline COV MEAN $_{\text {ME }}$ & 14.9 & 1,239 & 0.0001 & 3.5 & 6,239 & 0.0024 \\
\hline $\mathrm{COV}_{\text {RATE }}$ & 12.8 & 1,239 & 0.0004 & 3.0 & 6,239 & 0.0071 \\
\hline $\mathrm{COV}_{\text {MAX }}$ & 11.4 & 1,239 & 0.0009 & 2.4 & 6,263 & 0.0307 \\
\hline $\mathrm{H}_{\text {RATE }}$ & 3.6 & 1,154 & 0.0589 & 11.2 & 6,154 & $<0.0001$ \\
\hline Leaf RATE & 0.8 & 1,144 & 0.3604 & 8.7 & 6,144 & $<0.0001$ \\
\hline Emerg $_{\mathrm{SDD}}$ & 9.5 & 1,154 & 0.0024 & 1.2 & 6,154 & 0.3317 \\
\hline FlosDD & 49.4 & 1,125 & $<0.0001$ & 10.6 & 6,125 & $<0.0001$ \\
\hline
\end{tabular}

Table B6. Pairwise comparisons of cover crop traits in the cover crop trials depending on combined crop family $\mathrm{x}$ area of origin factors using a non-parametric Dunn test. All pairwise were tested but only the significative comparisons are described. Crop families are abbreviated: Asteraceae (Astera.), Brassicaceae (Brassica.), Fabaceae (Faba.), Poaceae (Poa.) and Polygonaceae (Polyg.). Area of origin is abbreviated: temperate (Temp.) and tropical (Trop.).

\begin{tabular}{|c|c|c|c|c|}
\hline Crop trait & Factor & & $\mathrm{Z}$ & P.value \\
\hline \multirow{2}{*}{$\mathrm{COV}_{\text {MEAN }}$} & Astera. Temp. & Faba. Temp. & 2.21 & 0.0134 \\
\hline & Faba. Temp. & Poa. Trop & -2.27 & 0.0114 \\
\hline \multirow{2}{*}{$\mathrm{COV}_{\text {RATE }}$} & Astera. Temp. & Faba. Temp. & 2.63 & 0.0043 \\
\hline & Faba. Temp. & Poa. Trop & -2.59 & 0.0049 \\
\hline \multirow{2}{*}{$\mathrm{COV}_{\text {MAX }}$} & Faba. Temp. & Faba. Trop. & -3.38 & 0.0004 \\
\hline & Faba. Temp. & Poa. Trop & -2.66 & 0.0039 \\
\hline \multirow{8}{*}{$\mathrm{H}_{\mathrm{RATE}}$} & Astera. Temp. & Faba. Temp. & 3.55 & 0.0002 \\
\hline & Faba. Temp. & Faba. Trop. & -4.18 & $<0.0001$ \\
\hline & Astera. Temp. & Poa. Temp. & 2.64 & 0.0041 \\
\hline & Faba. Trop. & Poa. Temp. & 2.27 & 0.0116 \\
\hline & Brassica. Temp. & Poa. Trop. & -3.19 & 0.0007 \\
\hline & Faba. Temp. & Poa. Trop. & -5.43 & $<0.0001$ \\
\hline & Faba. Trop. & Poa. Trop. & -3.20 & 0.0007 \\
\hline & Poa. Temp. & Poa. Trop. & -3.99 & $<0.0001$ \\
\hline \multirow{7}{*}{ Leaf $_{\text {RATE }}$} & Astera. Temp. & Poa. Temp. & 2.04 & 0.0205 \\
\hline & Brassica. Temp. & Poa. Temp. & 2.35 & 0.0094 \\
\hline & Faba. Temp. & Poa. Temp. & 2.88 & 0.0019 \\
\hline & Faba. Trop. & Poa. Temp. & 4.32 & $<0.0001$ \\
\hline & Faba. Temp. & Poa. Trop. & 2.25 & 0.0124 \\
\hline & Faba. Trop. & Poa. Trop. & 3.85 & $<0.0001$ \\
\hline & Poa. Temp. & Polyg. Temp. & -2.22 & 0.0131 \\
\hline Emerg $_{\mathrm{SDD}}$ & Brassica. Temp. & Faba. Trop. & -2.01 & 0.0223 \\
\hline \multirow{6}{*}{ Flo $_{S D D}$} & Astera. Temp. & Poa. Temp. & -2.52 & 0.0057 \\
\hline & Faba. Temp. & Poa. Temp. & -2.45 & 0.0072 \\
\hline & Faba. Trop. & Poa. Temp. & -2.29 & 0.0111 \\
\hline & Faba. Trop. & Poa. Trop. & 2.18 & 0.0146 \\
\hline & Poa. Temp. & Poa. Trop. & 3.04 & 0.0012 \\
\hline & Poa. Temp. & Polyg. Temp. & 2.79 & 0.0026 \\
\hline
\end{tabular}


(a)

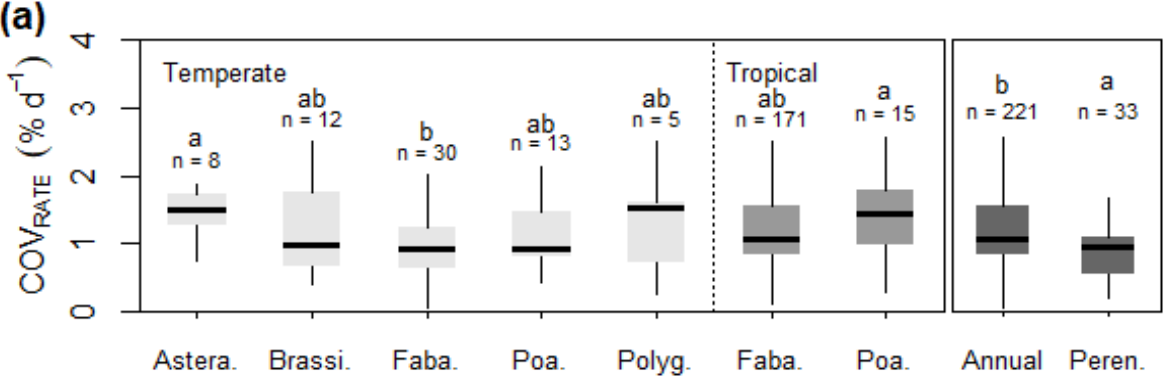

(c)

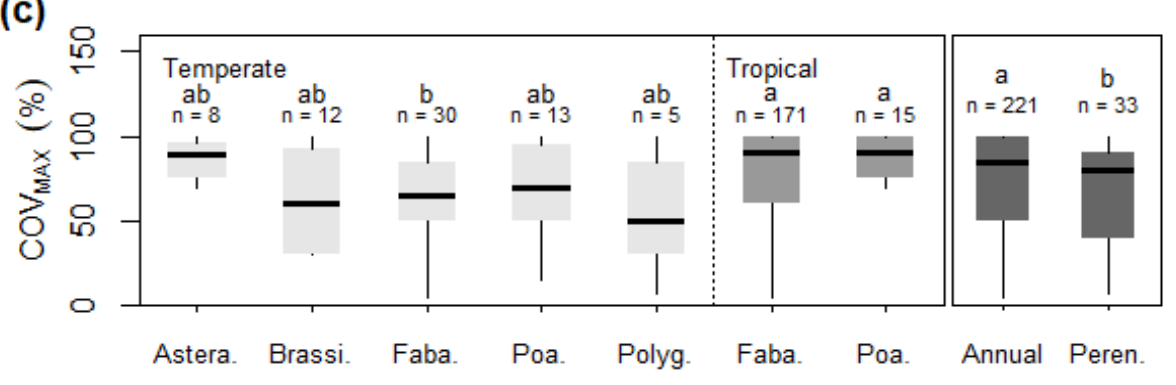

(e)

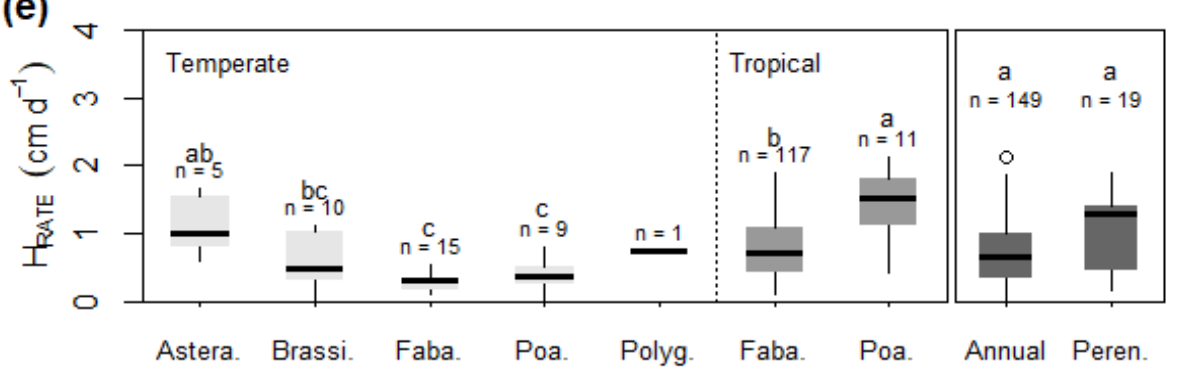

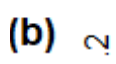

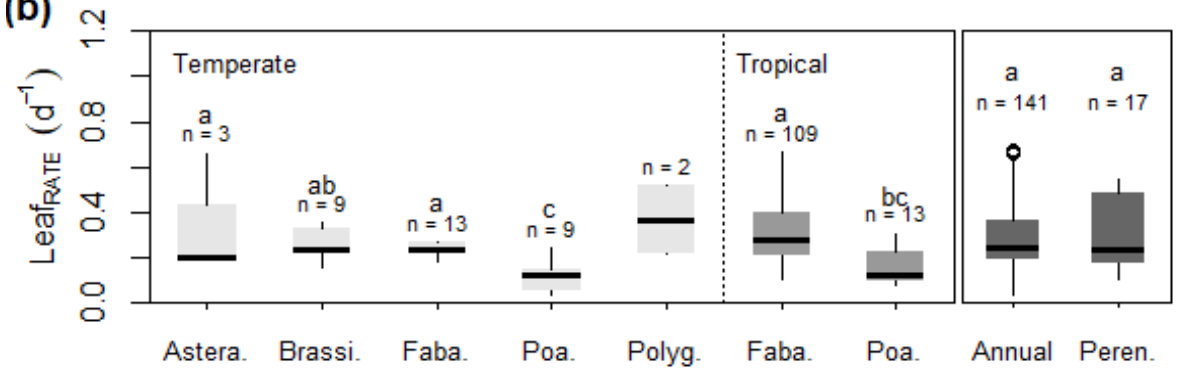

(d)

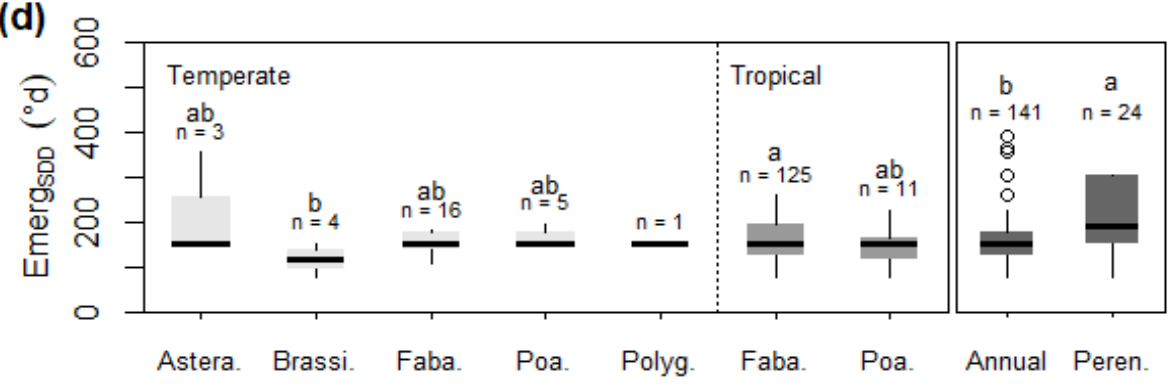

(f)

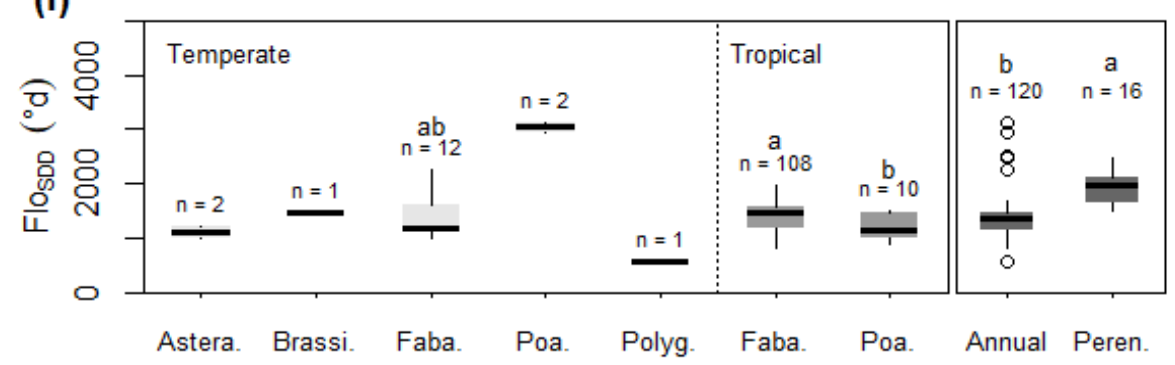

Fig B2. Rate of increase in ground cover (COV RATE, a), leaf appearance rate (Leaf $f_{\text {RATE, }}$ b), maximum ground cover (COV MAX, $_{\text {, }}$, thermal time for emergence $\left(\right.$ Emerg $\left._{S D D}, d\right)$, rate of increase in height $\left(\mathrm{H}_{\mathrm{RATE}}, \mathrm{e}\right)$ and thermal time for flowering (FlosDD, $\mathrm{f}$ ) of cover crop used in the cover crop trials depending on the crop family and area of origin (temperate or tropical) on one hand and the life cycle in the other hand (annual or perennial). Crop families are abbreviated: Asteraceae (Astera.), Brassicaceae (Brassica.), Fabaceae (Faba.), Poaceae (Poa.) and Polygonaceae (Polyg.). Life cycle is abbreviated: perennial (Peren.). The number of samples in each category is indicated by " $n$ ". The differences between combinations of factors were tested using a Dunn test and indicated by letters $a, b$ and $c$. 

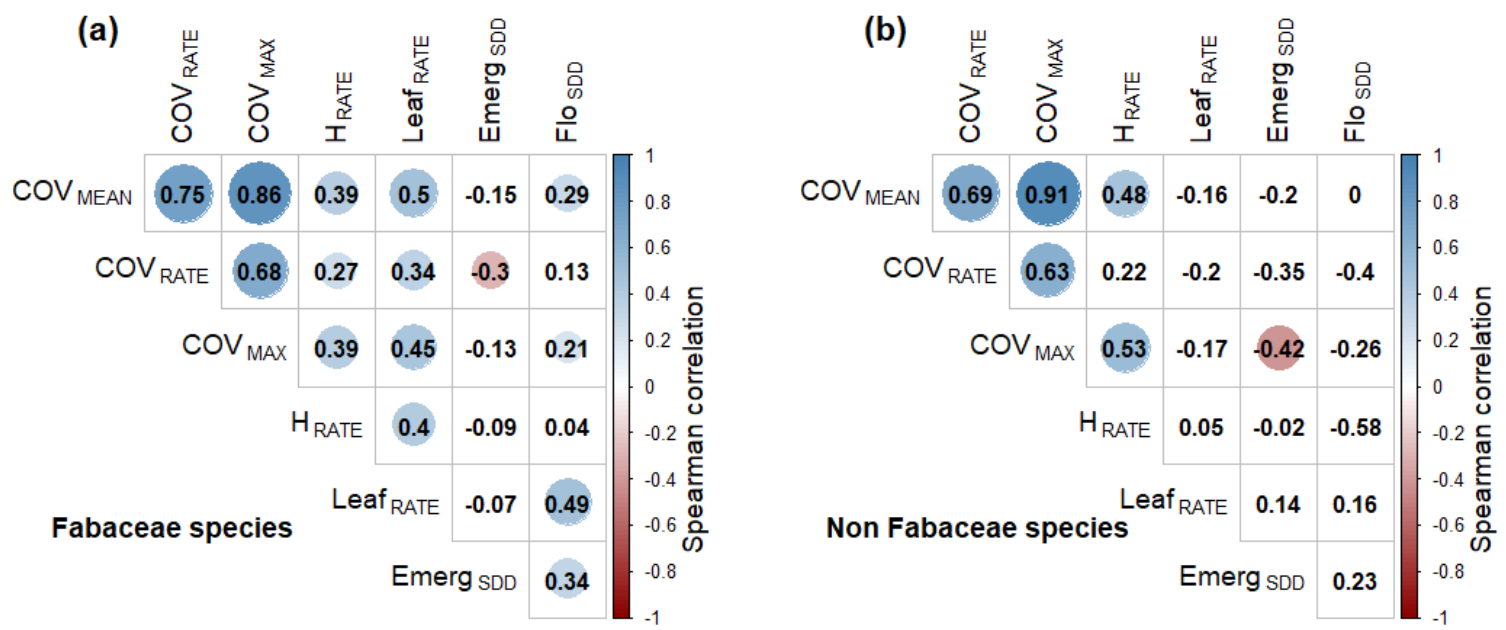

Fig B3. Spearman correlation between cover crop traits in the Fabaceae (a) or non-Fabaceae species (b) in the cover crop trials. In Fabaceae, the number of individuals was 201 for $\mathrm{COV}_{\text {MEAN }} \mathrm{COV}_{\text {RATE }}$ and $\mathrm{COV}_{\text {MAX }}$, and 132, 122, 141 and 120 for HRATE, Leaf $\mathrm{H}_{\mathrm{RATE}}$, Emerg and FlosDD, respectively. In non-Fabaceae, the number of individuals was 53 for $\mathrm{COV}_{\mathrm{MEAN}}$,

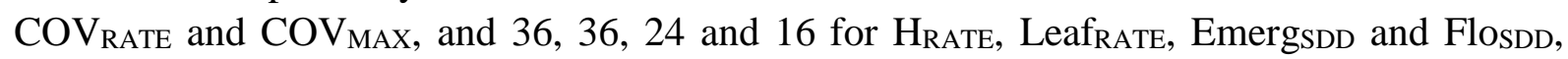
respectively. 
Table B7. Variance analysis on weed control efficiency in terms of ground cover (WCECov) or dry mass $\left(\mathrm{WCE}_{\mathrm{DM}}\right)$ in the weed control trials using a mixed linear model with the crop type (pure or mixture) or the combined crop family $\mathrm{x}$ area of origin within pure crops as fixed effects, and the trial identification as random effect.

\begin{tabular}{|c|c|c|c|c|c|c|}
\hline & \multicolumn{3}{|c|}{ Crop type (pure vs. mixture) } & \multicolumn{3}{|c|}{ Family $x$ area of origin (pure) } \\
\hline Crop trait & $\mathrm{F}$ & df & $\mathrm{p}$ & $\mathrm{F}$ & $\mathrm{df}$ & $\mathrm{P}$ \\
\hline $\mathrm{WCE}_{\mathrm{COV}}$ & 0.03 & 1,66 & 0.8652 & 8.34 & 5,36 & $<0.0001$ \\
\hline $\mathrm{WCE}_{\mathrm{DM}}$ & 0.78 & 1,41 & 0.3807 & 9.88 & 4,22 & 0.0001 \\
\hline
\end{tabular}

Table B8. Pairwise comparisons of weed control efficiency in the weed control trials depending on combined crop family $\mathrm{x}$ area of origin factors using a non-parametric Dunn test. All pairwise were tested but only the significative comparisons are described. Crop families are abbreviated: Asteraceae (Astera.), Brassicaceae (Brassica.), Fabaceae (Faba.), Poaceae (Poa.) and Polygonaceae (Polyg.). Area of origin is abbreviated: temperate (Temp.) and tropical (Trop.).

\begin{tabular}{|l|l|l|r|r|}
\hline Crop trait & Factor & Z & & P.value \\
\hline \multirow{5}{*}{ WCE $_{\text {COV }}$} & Astera. Temp. & Brassica. Temp. & 3.28 & 0.0005 \\
\cline { 2 - 5 } & Astera. Temp. & Faba. Temp. & 2.21 & 0.0136 \\
\cline { 2 - 5 } & Astera. Temp. & Faba. Trop. & 3.45 & 0.0003 \\
\cline { 2 - 5 } & Brassica. Temp. & Poa. Temp. & -2.23 & 0.0130 \\
\cline { 2 - 5 } & Faba. Trop. & Poa. Temp. & -2.08 & 0.0186 \\
\cline { 2 - 5 } & Brassica. Temp. & Poa. Trop. & -2.96 & 0.0015 \\
\cline { 2 - 5 } & Faba. Trop. & Poa. Trop. & -3.49 & 0.0002 \\
\hline \multirow{4}{*}{ WCE $_{\text {DM }}$} & Astera. Temp. & Faba. Temp. & 2.55 & 0.0054 \\
\cline { 2 - 5 } & Astera. Temp. & Faba. Trop. & 2.98 & 0.0014 \\
\cline { 2 - 5 } & Faba. Temp. & Poa. Trop. & -2.92 & 0.0018 \\
\cline { 2 - 5 } & Faba. Trop. & Poa. Trop. & -3.62 & 0.0001 \\
\hline
\end{tabular}



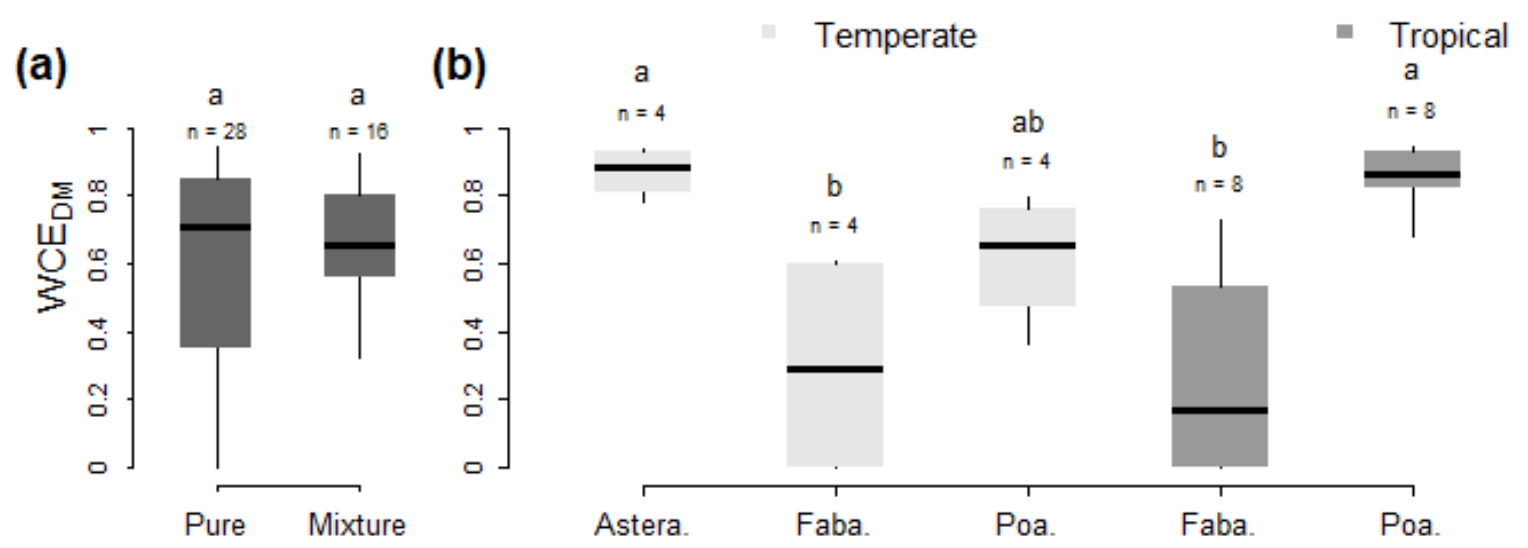

(c)

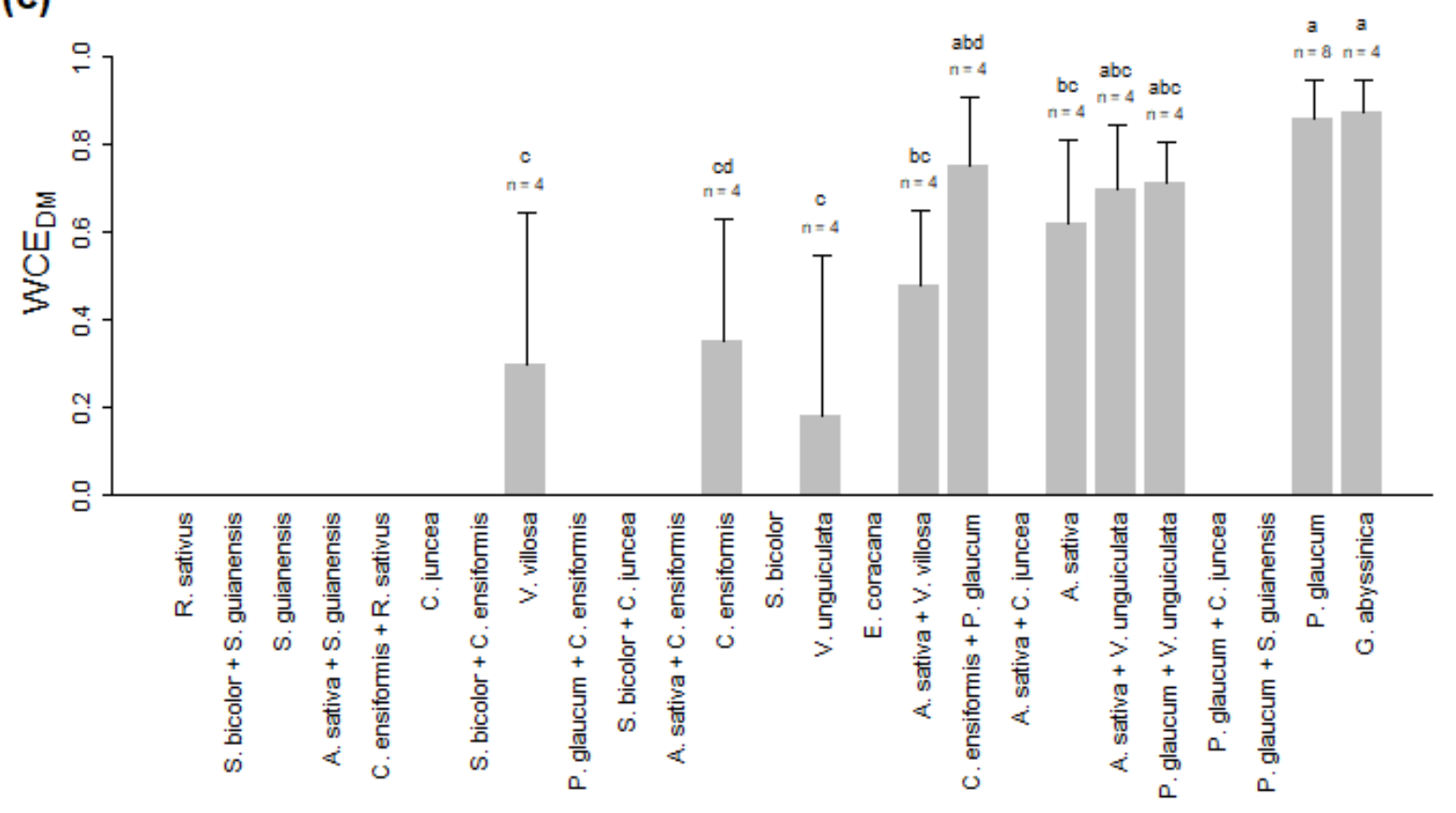

Fig. B4. Weed control efficiency in terms of weed dry mass $\left(\mathrm{WCE}_{\mathrm{DM}}\right)$ in pure cover plots or a mixture of two cover crops (a), depending on crop family and area of origin in pure plots (b) or depending on cover crop species (c) in the four weed control trials. Crop families are abbreviated for Asteraceae (Astera.), Brassicaceae (Brassica.), Fabaceae (Faba.) and Poaceae (Poa.). The difference between factors was tested using Dunn's test and is indicated by letters $a, b$ and $c$. The number of samples in each category is indicated by " $n$ ". 
(a)

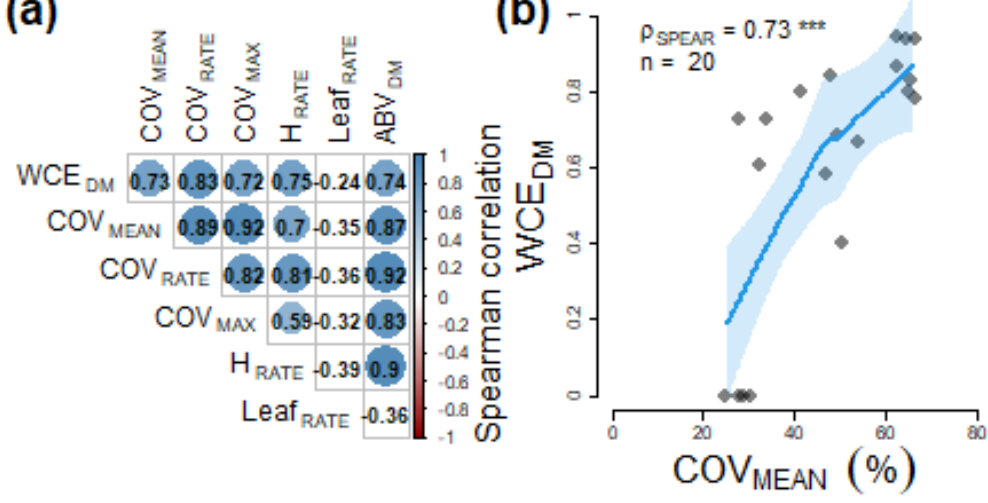

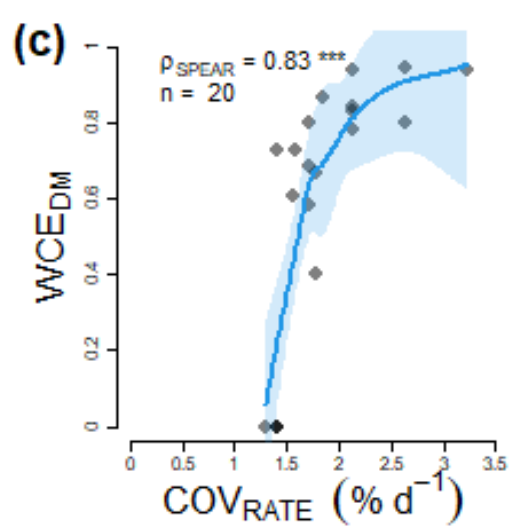
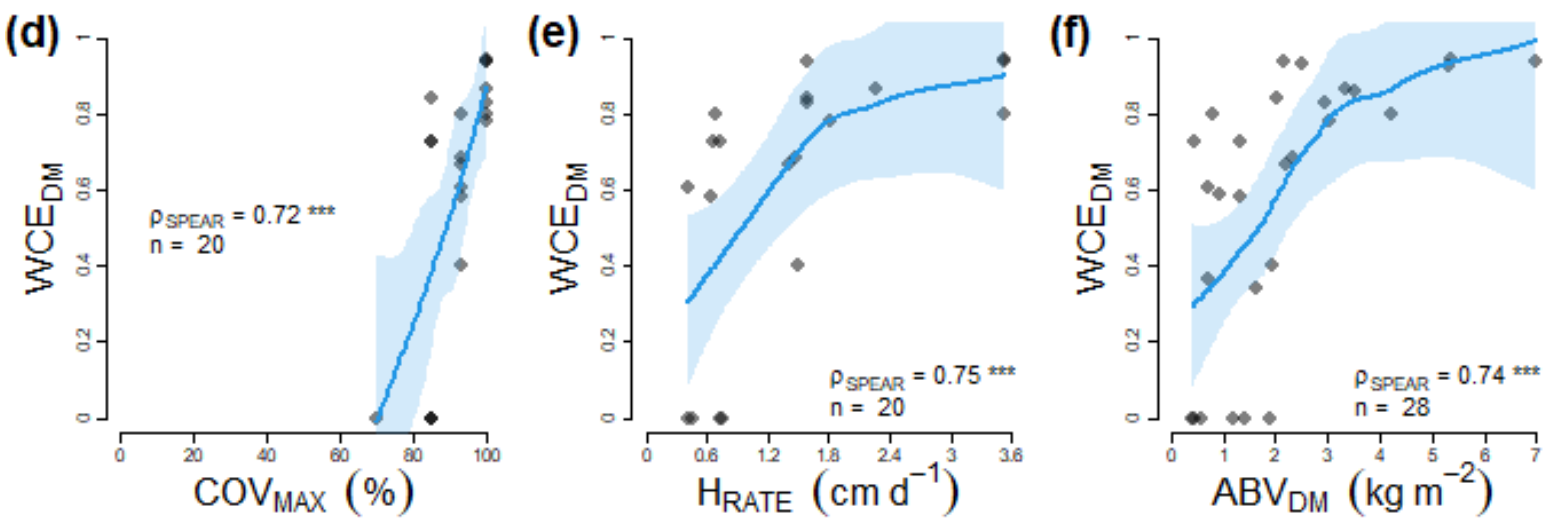

Fig B5. Spearman correlation between cover crop traits in pure stand in the weed control trials (a). Significant positive and negative correlations are in blue and red circles, respectively. Change in weed control efficiency based on weed dry mass $\left(\mathrm{WCE}_{\mathrm{DM}}\right)$ in pure crops depending on cover crop traits: mean ground cover $\left(\mathrm{COV}_{\mathrm{MEAN}}, \mathrm{b}\right)$, rate of increase in ground cover $\left(\mathrm{COV}_{\mathrm{RATE}}, \mathrm{c}\right)$, maximum ground cover $\left(\mathrm{COV}_{\mathrm{MAX}}, \mathrm{d}\right)$, rate of increase in height $\left(\mathrm{H}_{\mathrm{RATE}}, \mathrm{e}\right)$ and aboveground dry mass $\left(\mathrm{ABV}_{\mathrm{DM}}, \mathrm{f}\right)$ are detailed. The number of samples $(\mathrm{n})$ and the Spearman correlation coefficient ( $\rho_{\text {SPEAR }}$ ) are indicated. Polynomial smooth regression between weed control and crop traits were added (blue line) with confidence interval (area shaded in light blue). 